\title{
Hadimopanella oezgueli Gedik, 1977: a palaeoscolecidan sclerite useless for taxonomic purposes
}

\author{
Tania Barragán, Jorge Esteve, Diego C. García-Bellido, \\ Samuel Zamora, and J. Javier Álvaro
}

\begin{abstract}
A new assemblage of Hadimopanella oezgueli Gedik, 1977 is described from the middle Caesaraugustan (middle Cambrian) part of the Genestosa Member (Oville Formation) in the Cantabrian Mountains, northern Spain. Sclerites occur disarticulated and display distinct diagenetic processes, with authigenic chlorites occluding primary porosity and secondary fissures. Sclerite distribution was controlled by patchy development of epibenthic multispecies clumps on shell (both carbonate and clayey) substrates. A joint biometric and statistical analysis in both dorsal and lateral views of disarticulated sclerites allows characterization of two distinct morphotypes. These are compared with other occurrences of $\mathrm{H}$. oezgueli sclerites from other margins of Gondwana and the Siberian Platform, as a result of which, another morphotype is identified. Two main inferences can be drawn: (i) different ventral trunk-sided sclerites of a same scleritome comprise different sclerite morphotypes and (ii) one distinct sclerite morphotype occurs in different genera and species. These results emphasize the idea that the diagnostic features that characterize the parataxon $\mathrm{H}$. oezgueli should not be used for (bio) taxonomic classification of palaeoscolecidan scleritomes.
\end{abstract}

Tania Barragán. Centro de Astrobiología (CSIC/INTA), Ctra. de Torrejón a Ajalvir km 4, 28850 Torrejón de Ardoz, Spain, barragangt@cab.inta-csic.es

Jorge Esteve.Centre of Biology, Earth and Environmental Sciences, University of West Bohemia at Plzeň, 30619 PIzeň, Czech Republic, jorgeves@unizar.es

Diego C. García-Bellido. Environment Institute,School of Earth \& Environmental Sciences, University of Adelaide, Adelaide, SA 5005, Australia, Diego.Garcia-Bellido@adelaide.edu.au

Samuel Zamora. Instituto Geológico y Minero de España, c/ Manuel Lasala, 44 - 9 B, 50006 Zaragoza, Spain, s.zamora@igme.es

J. Javier Álvaro. Centro de Astrobiología (CSIC/INTA). Ctra. de Torrejón a Ajalvir km 4, 28850 Torrejón de Ardoz, Spain, alvarobjj@cab.inta-csic.es

Keywords: biometric analysis; parataxonomy; taphonomy; Cambrian; Gondwana 


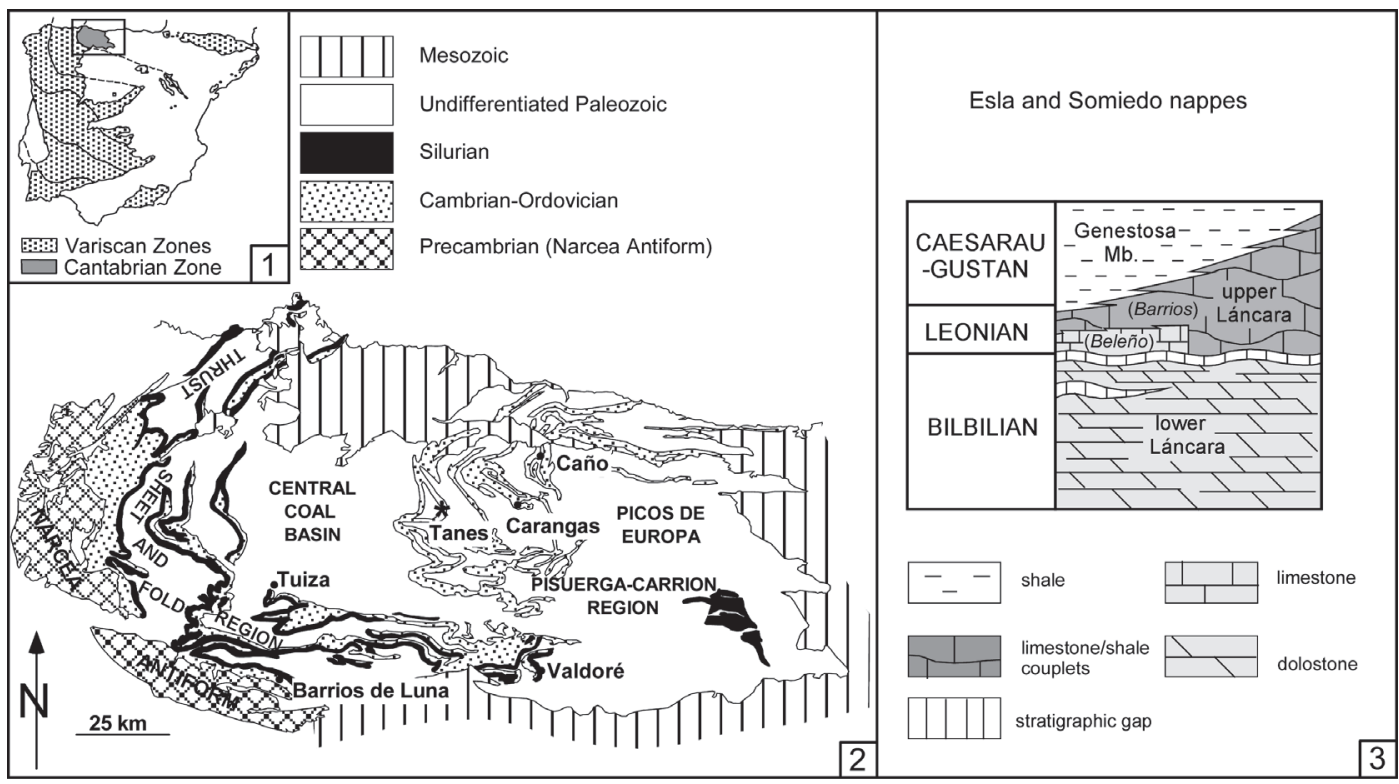

FIGURE 1. (1) Geological sketch of the Iberian Peninsula showing the setting of the Cantabrian Mountains. (2) Geological setting of the study area in Tanes, Cantabrian Mountains. (3) Stratigraphic log of the lower-middle Cambrian transition in the Cantabrian Mountains.

\section{INTRODUCTION}

Palaeoscolecids were vermiform metazoans characterized by an annulated long, slender, cylindrical body armoured with organic or organo-phosphatic button-like sclerites arranged in linear patterns. They were common components of Cambrian-Late Silurian marine benthic communities (Conway Morris; 1997; García-Bellido et al., 2013; Hou and Bergström, 1994; Kraft and Mergl, 1989; Müller and Hinz-Schallreuter, 1993; Zhang and Pratt, 1996). Despite the finding of complete and well-preserved palaeoscolecidan cuticles in the lower Cambrian Chengjiang Lagerstätte of China (Hou and Bergström, 1994; Zhang and Pratt, 1996), the middle Cambrian of Australia (Müller and Hinz-Schallreuter, 1993), and the Lower Ordovician of Bohemia (Hinz et al., 1990), some aspects related to both their phylogenetic relationships with ecdysozoan groups and lifestyle are still under discussion (Botting et al., 2012; Conway Morris and Peel, 2010; Han et al., 2007a, 2007b, 2007c; Harvey et al., 2010; Wills et al., 2012).

Their first descriptions were based on compressed body fossils (e.g., Conway Morris and Robison, 1986, Robison, 1969; Ulrich, 1878; Whittard, 1953). Their disarticulated sclerites were found worldwide as dregs after limestone etching with problems to assign them to specific taxa and were described under different generic names, such as Hadimopanella Gedik, 1977, Kaimenella
Märss, 1988 and Milaculum Müller, 1973 (e.g., Bendix-Almgreen and Peel, 1988; Bengtson, 1977; Gedik, 1977, 1989; Märss, 1988; Peel and Larsen, 1984; van den Boogard, 1983, 1988, 1989a, 1989b; Wrona, 1982, 1987). They were subsequently integrated with palaeoscolecidan body fossils (Kraft and Mergl, 1989; van den Boogaard, 1989a, 1989b). One well-known cosmopolitan sclerite is Hadimopanella oezgueli Gedik, 1977, originally described from Turkey, and significantly abundant in Cambrian sediments of Siberia and Gondwana.

A new assemblage of Hadimopanella isolated sclerites from the middle Cambrian of the Cantabrian Mountains (northern Spain) is reported here. The aim of this paper is to offer a quantitative analysis of this assemblage in order to characterize the wide morphological variability of the parataxon. A comparison with other isolated Hadimopanella sclerites found elsewhere is provided along with a brief discussion of its (para)taxonomic usefulness. Finally, a discussion of diagenetic processes and palaeoecological constrains is included.

\section{GEOLOGICAL SETTING AND STRATIGRAPHY}

The Cantabrian Mountains (Figure 1.1-2) are of prime importance in understanding the benthic community replacements associated with the faunal turnover that characterize the lower-middle Cambrian boundary interval (Álvaro et al., 2013). 
The remnants of the subtropical carbonate platform preserved in this part of West Gondwana shows the stepwise record of: (i) the occurrence of the youngest archaeocyathan-microbial reefs of West Gondwana (Perejón and Moreno-Eiris, 2003) associated with ooidal shoal complexes rich in endemic trilobites and low-diversity skeletonized microfossils (Álvaro, 2007; Clausen and Álvaro, 2006); (ii) the onset of a regional erosive unconformity within the Láncara Formation marking the lower-middle Cambrian boundary (Álvaro et al., 2000; Aramburu et al., 1992; Aramburu and García Ramos, 1993; van der Mohr, 1969), bearing an indeterminate biostratigraphic gap laterally correlatable into the Montagne Noire (Wotte et al., 2007); and (iii) the stepwise immigration of new trilobite families, linguliform brachiopods and highly diverse skeletonized microfossils (Clausen and Álvaro, 2006; Sdzuy, 1968, 1995; Wotte, 2006, 2009a, 2009b; Wotte and Mergl, 2007) on middle Cambrian transgressive offshore-dominated substrates.

The occurrence of disarticulated sclerites of Hadimopanella oezgueli is related to this earliest mid-Cambrian immigration of shelly fauna. Although its presence was reported from the Barrios (or griotte) facies of the upper Láncara Member (Fernández-Remolar, 2001; van den Boogaard, 1983) (Figure 1.3), unreported limestone interbeds of the overlying Genestosa Member (Oville Formation) are also rife with sclerites. These were sampled in trilobite-rich wackestoneto-packstone tempestites of the Genestosa Member at Tanes (Sdzuy, 1968). The fossiliferous limestones belong to the Pardailhania hispida Zone (mid Caesaraugustan) based on its trilobite content (Liñán et al., 1993; Sdzuy, 1968).

\section{MATERIAL AND METHODS}

This work is based on a collection of Hadimopanella oezgueli-type sclerites sampled after etching of bioclastic limestones from the Genestosa Member and their comparison with other sclerites of the same parataxon previously reported from other margins of Gondwana and the Siberian Platform. Isolated sclerites are used below in their parataxonomic concept, so outside any ortho- or biotaxonomic concept of Bengtson's definition (1985): "a parataxon is a conceptual taxon belonging to a taxonomic system that by formal decision is outside the orthotaxonomic (or biological) system covering the same group of organisms." Only complete palaeoscolecidan scleritomes are reported as (bio)taxonomic entities (Ivantsov and
Wrona, 2004), whereas disarticulated sclerites are referred to as parataxons.

In the studied material from the Genestosa Member, 78 sclerites of $H$. oezgueli were selected after etching to carry out biometric and statistical analyses. Smaller specimens, less than $100 \mu \mathrm{m}$ in diameter, were usually overlooked or hard to extract during picking. Specimens are phosphatic or phosphatized, and usually preserve all the ornamentation details. Several specimens clearly show erosive facets, which are explained later.

Image J-Software (Abràmoff et al., 2004) was used to estimate linear and surface measurements in the dorsal view of sclerites examples from Genestosa Member $(n=33)$ and from other published articles $(n=41)$. Mainly five groups of parameters were measured in dorsal view: (i) largest $\left(D_{\max }\right)$, shortest $\left(D_{\min }\right)$, and median $\left(D_{m e}=D_{\max }+D_{\min } / 2\right)$ diameters of outer surface; (ii) largest ( $d_{\text {max }}$ ), shortest $\left(d_{\text {min }}\right)$, and median $\left(d_{\text {me }}\right)$ diameters of middle surface, reported from the outline of the latter (tuberculated surface included); (iii) largest $\left(d_{\max }\right)$, shortest $\left(d_{\min }\right)$, and median $\left(d_{m e}\right)$ diameters of the tuberculated surface, (iv) number of tubercles (no. tubercles) and diameter of largest and smallest tubercles plus their tip diameters ( $\varnothing$ largest tubercle, $\varnothing$ smallest tubercle, $\varnothing$ tip); and (v) a measure of eccentricity, based on the distance between the centres of the outer and the tuberculated surface (ed). The relationships built from the latter measures are used in the statistical analyses were: $D_{m e} / d_{m e}, D_{m e}-d_{m e}^{\prime} / D, d '-d /$ $D, D_{\max } / D_{\min }, d_{\max } / d_{\min }$, ed/d $/ d_{\max }$, no. tubercles/ $\mathrm{d}_{\mathrm{me}}, \varnothing$ largest tubercle/ø tip, $\varnothing$ smallest tubercle/ $\varnothing$ tip, and $\varnothing$ largest tubercle/ø smallest tubercle. A sketch of main measures is illustrated in Figure 2.1 and a dataset of all these values is specified in Appendices 1,2 and 3. Several measures were made in lateral view, such as radius of sclerite base $(r)$; heights of marginal brim $\left(h_{1}\right)$, middle surface $\left(h_{2}\right)$, and tuberculated surface $\left(h_{3}\right)$; and slopes of marginal brim ( $\operatorname{tg} \alpha_{1}$ ), middle surface (tg $\alpha_{2}$ ), and tuberculated surface ( $\operatorname{tg} \alpha_{3}$ ); as well as the width of tubercle base and tip diameters tubercles and the relationships computed were $h / h_{1}, h / h_{2}, h /$ $h_{3}, r / h, \operatorname{tg} \alpha_{1}, \operatorname{tg} \alpha_{2}, \operatorname{tg} \alpha_{3}$, and base/tip. The measures are illustrated in Figure 2.2, and their values are included in Appendix 4 and Appendix 5.

Histograms were made to determine the diameter frequency (maximum diameter of the outer surface, $D_{\max }$ ) measured in dorsal-view specimens and the height frequency (from base to 


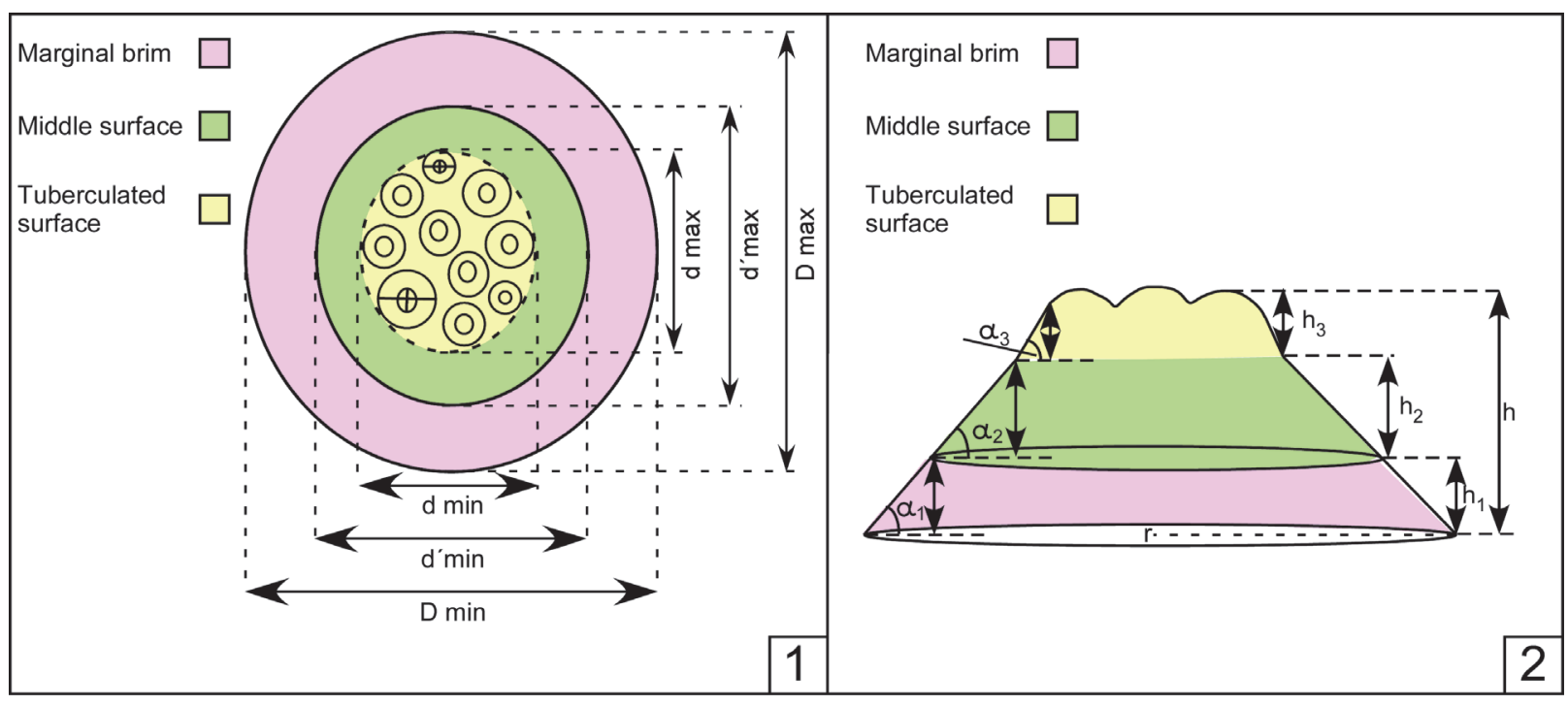

FIGURE 2. Principal parameters measured in dorsal (1) and lateral (2) views of Hadimopanella oezgueli sclerites from the Genestosa Member. Abbreviations: largest / shortest diameter of outline sclerite (Dmax/Dmin), middle surface (d'max/d'min) and tuberculated surface (dmax/dmin); height of marginal brim $\left(\mathrm{h}_{1}\right)$, middle surface $\left(\mathrm{h}_{2}\right)$, and tuberculated surface $\left(h_{3}\right)$; slope of marginal brim $\left(\alpha_{1}\right)$, middle surface $\left(\alpha_{2}\right)$, and tuberculated surface $\left(\alpha_{3}\right)$; radius base $(r)$.

the tip tubercle) measured in lateral-view specimens (Figure 3.1-2); the numerical values of histograms are summarized in Appendix 6.

Cluster analysis (following Ward, 1963) and principal coordinates analysis (PCoA; Gower, 1966) have been carried out to recognize morphotypes in dorsal and lateral views. The cluster analysis illustrated in Figures 4 and 5 include both new sclerites from the Genesosa Member (this work) and other sclerites referred to $H$. oezgueli from the Láncara Formation (van den Boogaard, 1983) in Spain, the Mila Formation of Iran (Wrona and Hamdi, 2001), the Monastery Creek Formation of Australia (Müller and Hinz-Schallreuter, 1993), the Campo Pisano Formation of Sardinia (Elicki, 2006), the Korrelasyonunda Formation (Gedik, 1977), where the holotype was described, and the Çal Tepe Formation (Gedik, 1989; Sarmiento et al., 2001) of Turkey, and the Ülgase-Kallavere Formation of Kirgizia (Märss, 1988). The Siberian sclerites appear in the Sinsk Formation and belong to the following classified species: sclerite from the dorsal side of the trunk (S1) in Palaeoscolex lubovae Ivantsov and Wrona, 2004 (Wronascolex lubovae sensu Ivantsov and Zhuravlev, 2005; in García-Bellido et al., 2013; Topper et al., 2010), sclerites (S2 and S3) of Sahascolex labyrinthus Ivantsov and Wrona, 2004 (Corrallioscolex labyrinthus sensu Ivantsov and Zhuravlev, 2005; in Topper et al., 2010), sclerites (S4 and S5) of
Palaeoscolex sp. Ivantsov and Wrona, 2004 or Wronascolex sp. sensu Ivantsov and Zhuravlev (2005) (see García-Bellido et al., 2013); Ps1, Ps2, and Ps3 represent different sclerite morphotypes from the ventral side of the trunk of Palaeoscolex spinosus Ivantsov and Wrona, 2004 (Wronascolex spinosus sensu Ivantsov and Zhuravlev, 2005; in García-Bellido et al., 2013; Topper et al., 2010).

Multivariate analyses were performed by statistics package PAST (Paleontological Statistics) version 1.97 Software (Hammer et al., 2001; Hammer and Harper, 2006).

Finally, spectral imaging by Scanning Electron Microscope (SEM) equipped with an energy-dispersive X-ray spectroscopy (EDS) method was performed to ascertain the chemical composition and to examine the internal structure of some sclerites.

\section{RESULTS}

Three statistical analyses of etched sclerites (histogram, cluster, and PCoA analyses) are described below.

\section{Histogram Analysis}

Sclerite-size frequency is assessed through dorsal-view measurements $(n=33)$ in Figure 3.1. The observed $D_{\max }$ size varies from 120 to $200 \mu \mathrm{m}$ and the average diameter from 130 to $160 \mu \mathrm{m}$, 


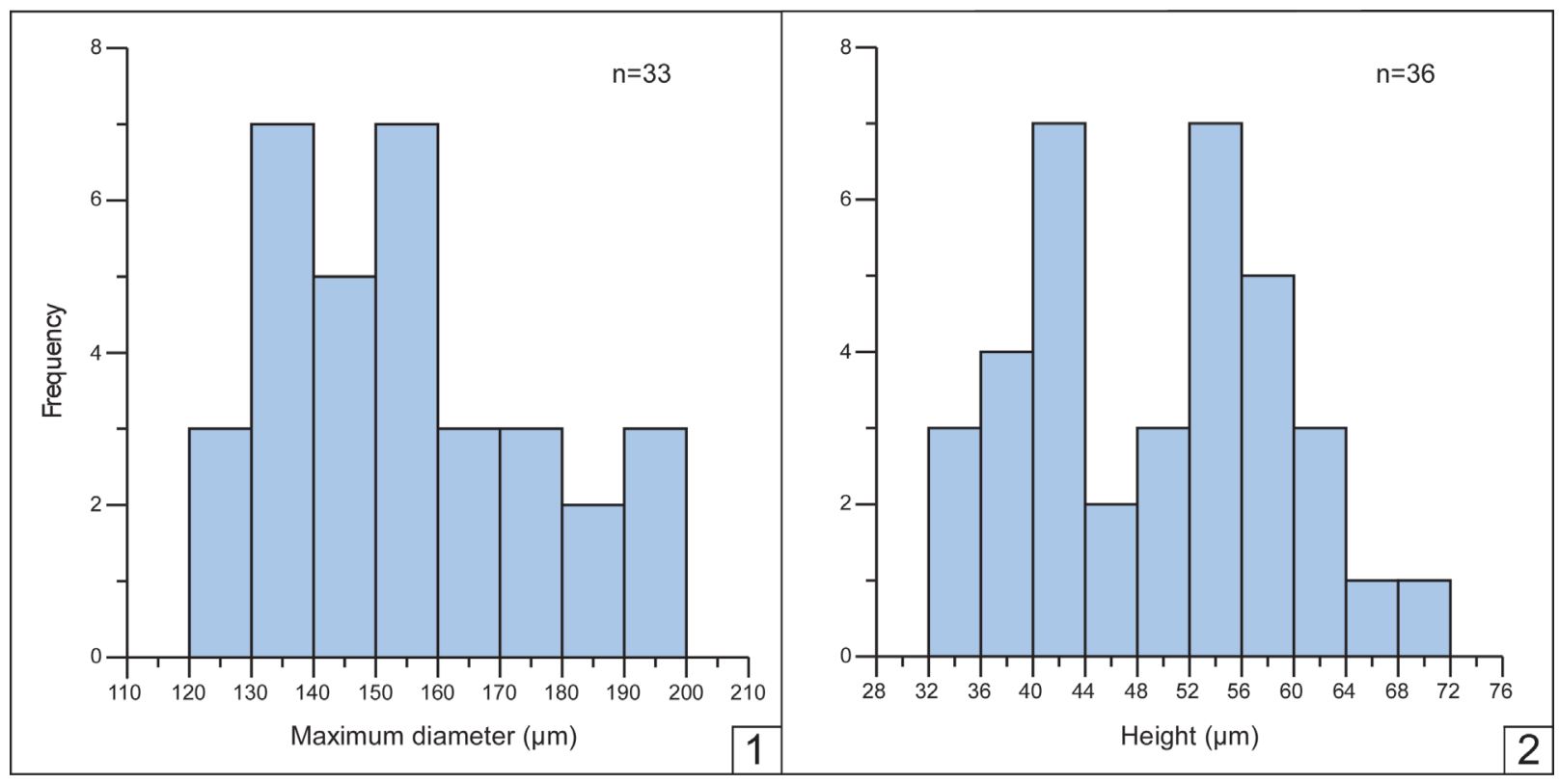

FIGURE 3. (1) Diameter frequency histogram (maximum diameter of outer surface, D max) of dorsal-view sclerites $(n=33)$. (2) Height frequency histogram (from base to the tubercle tip) of lateral-view sclerites $(n=36)$.

which represents $57 \%$ of the total selected sclerites. The size range fits well with the average size displayed by similar sclerites from the underlying Upper Láncara Member (van den Boogaard, 1983), with a range of $80-250 \mu \mathrm{m}$. The sclerite height frequency histogram measured from the base to the tip of tubercles in lateral view $(n=36)$ is illustrated in Figure 3.2. The height ranges between 32 and $72 \mu \mathrm{m}$; although most specimens are broadly distributed in two intervals, between $40-44 \mu \mathrm{m}$ and $52-60 \mu \mathrm{m}$, which represent $52 \%$ of the total selected sclerites.

\section{Cluster Analysis}

The cluster analysis of dorsal-view sclerites allows identification of two distinct morphotypes (A and $B$ ), both subdivided into two submorphotypes, although submorphotypes B is less distinct (Figure 4.1). These are described below following Müller and Hinz-Schallreuter's (1993) nomenclature:

1. Morphotype $A(n=16)$ includes two submorphotypes, A1 $(n=3)$ and A2 $(n=13)$. Submorphotype A1 (Figures 4.1, 5.1-2) includes sclerites with an elliptical and highly eccentric tuberculated surface (or nodular face sensu Bengtson, 1977), by comparison with the overall outline. Diameter of A1 sclerites ranges between 149 and $177 \mu \mathrm{m}$; they have 7 to 12 tubercles (or nodes) with a basal diameter ranging from 19 to $34 \mu \mathrm{m}$ in largest tubercles and near $14 \mu \mathrm{m}$ in smallest tubercles.
Most of the tubercles occur on an outer row forming an ellipse with only 1-3 tubercles in the centre; they are very heterogeneous in size and show a markedly sharp tip, and an occasional striated flank; these sclerites present a striated marginal brim, 10-15 $\mu \mathrm{m}$ wide, and a "middle surface", separating the tuberculated surface from the marginal brim, with an irregular width on average $20 \mu \mathrm{m}$. Submorphotype A2 (Figures 4.1, 5.3, 5.6-7, 5.10) includes sclerites, 114-191 $\mu \mathrm{m}$ in diameter, with a low eccentric, subelliptical-outlined tuberculated surface, which shows 8-15 tubercles $(7-21 \mu \mathrm{m}$ in diameter for smallest specimens, 16-39 $\mu \mathrm{m}$ in the largest ones); most of the tubercles are mainly placed on an outer row forming a circle or ellipse, although 1-3 tubercles can be closer to the centre. The tubercles are homogeneous in size and have a rounded tip with a striated flank; the brim, 3$31 \mu \mathrm{m}$ wide, is also striated or grooved and occasionally wavy; the middle surface is subcircular in outline and 10-25 $\mu \mathrm{m}$ wide.

2. Morphotype $B(n=17)$ includes submorphotypes B1 $(n=3)$ and B2 $(n=14)$. Submorphotype B1 sclerites (Figures $4.1,5.11$ ) are 138$166 \mu \mathrm{m}$ in diameter and show a rounded and slightly eccentric tuberculated surface. This bears six or seven homogeneous tubercles separated by marked grooves; the marginal brim, 5-20 $\mu \mathrm{m}$ wide, is grooved; the middle 


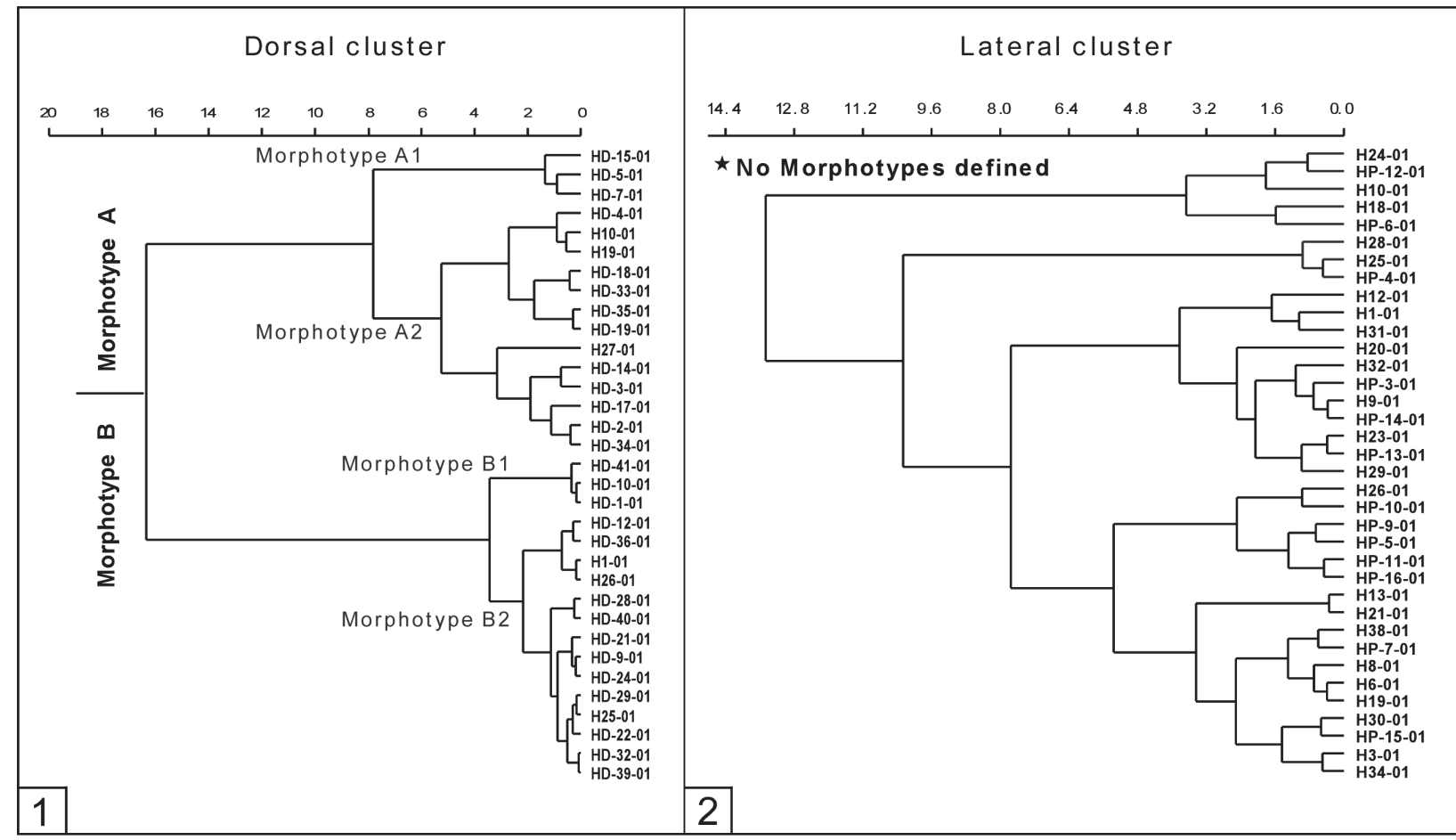

FIGURE 4. (1) Cluster diagram of dorsal-(1) and lateral-view (2) sclerites; morphotypes A1, A2, B1, and B2 are identified in (1), whereas no morphotypes can be recognized in (2).

surface is on average $20 \mu \mathrm{m}$ wide; this submorphotype has a broad middle surface in comparison with their marginal brim. Sclerites of type B2 (Figure 5.9, 5.14-16) are 116-168 $\mu \mathrm{m}$ in diameter, and show an eccentric and almost round or elliptical tuberculated surface. Some specimens exhibit a flat crest covered by a high number of tubercles $(>25)$, which represents the diagnostic character of Hadimopanella knappologica (Bengtson, 1977, Figure 5.9, 5.15). Seven to 28 tubercles form one or two rings surrounding a cluster of up to four tubercles in the centre; the largest diameter of tubercles ranges between 11 and $32 \mu \mathrm{m}$ and the smallest one between 9 and $23 \mu \mathrm{m}$. Tubercles display a high rounded tip and are either heterogeneous in size or homogeneous in the case of sclerites with a high number of tubercles. The brim, 5-17 $\mu \mathrm{m}$ wide, is striated or deeply grooved, and sometimes wavy. The width of the middle surface ranges between 10 and $27 \mu \mathrm{m}$ on average.

Cluster analysis in lateral-view sclerites (Figure 4.2) does not identify distinct morphotypes. The morphotypes determined in dorsal view show no correlation with lateral morphotypes.

\section{Principal Coordinate Analysis (PCoA)}

In order to compare the morphotypes described above with other occurrences of Hadimopanella oezgueli from Gondwana and Siberia (see measurements of other illustrated articles sclerites and relationship parameters in Appendices 2-3), a Principal Coordinates Analysis (PCoA) has been carried out with all dorsal-view sclerites (Figure 6.1).

The analysis shows three broad groups (the above-mentioned A1-A2 and B1-B2, and the new C) plus two isolated sclerites (two ventral trunksided sclerites of $W$. spinosus, Ps1 and Ps2). The sclerites yielded by the Genestosa limestone interbeds fall into groups $A$ and $B$; those from the Láncara and Ülgase-Kallavere formations into groups $A, B$, and $C$; those from the Mila and Monastery Creek formations into groups $A$ and $C$; that from the Campo Pisano Formation into group $A$; and those from Turkey into group $C$.

The Siberian sclerites are distributed as follows: S and Ps3 (or "Hadimopanella oezgueli"type) in groups $A$ and $C$ and sclerites Ps1 ("spiny coronata"-type) and Ps2 ("knappologica"-type; Bengtson, 1977) plot outside the three groups. As a result, different ventral-side trunk sclerites of a same scleritome comprise different sclerite mor- 


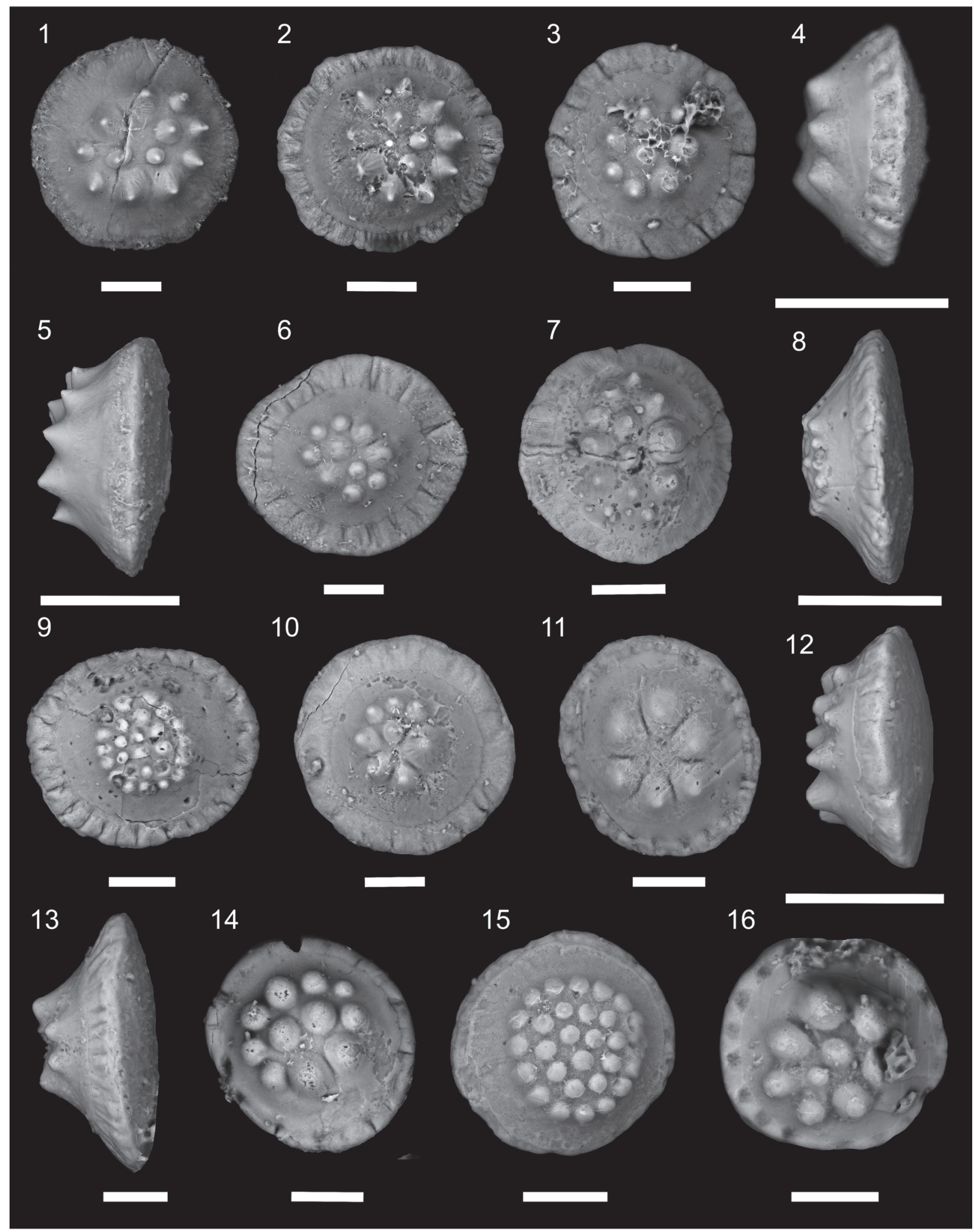

FIGURE 5. (1 to 16) SEM photographs of Hadimopanella oezgueli Gedik, 1977 sclerites from the Genestosa Member, middle Caesaraugustan. (1-2) Morphotype A1; $(3,6-7,10)$ Morphotype A2; (11) Morphotype B1; $(9,14-16)$ Morpthotype. B2. (4-5, 8, 12-13) Lateral-view of sclerites; scale bars for dorsal views equal $50 \mu \mathrm{m}$ and for lateral views scale bars equal $100 \mu \mathrm{m}$ (except no. $13=50 \mu \mathrm{m}$ ). Illustrated specimens are housed in the Instituto Geológico y Minero de España (IGME: MGM prefix), Spain: from MGM 1118K to MGM 1133K. 

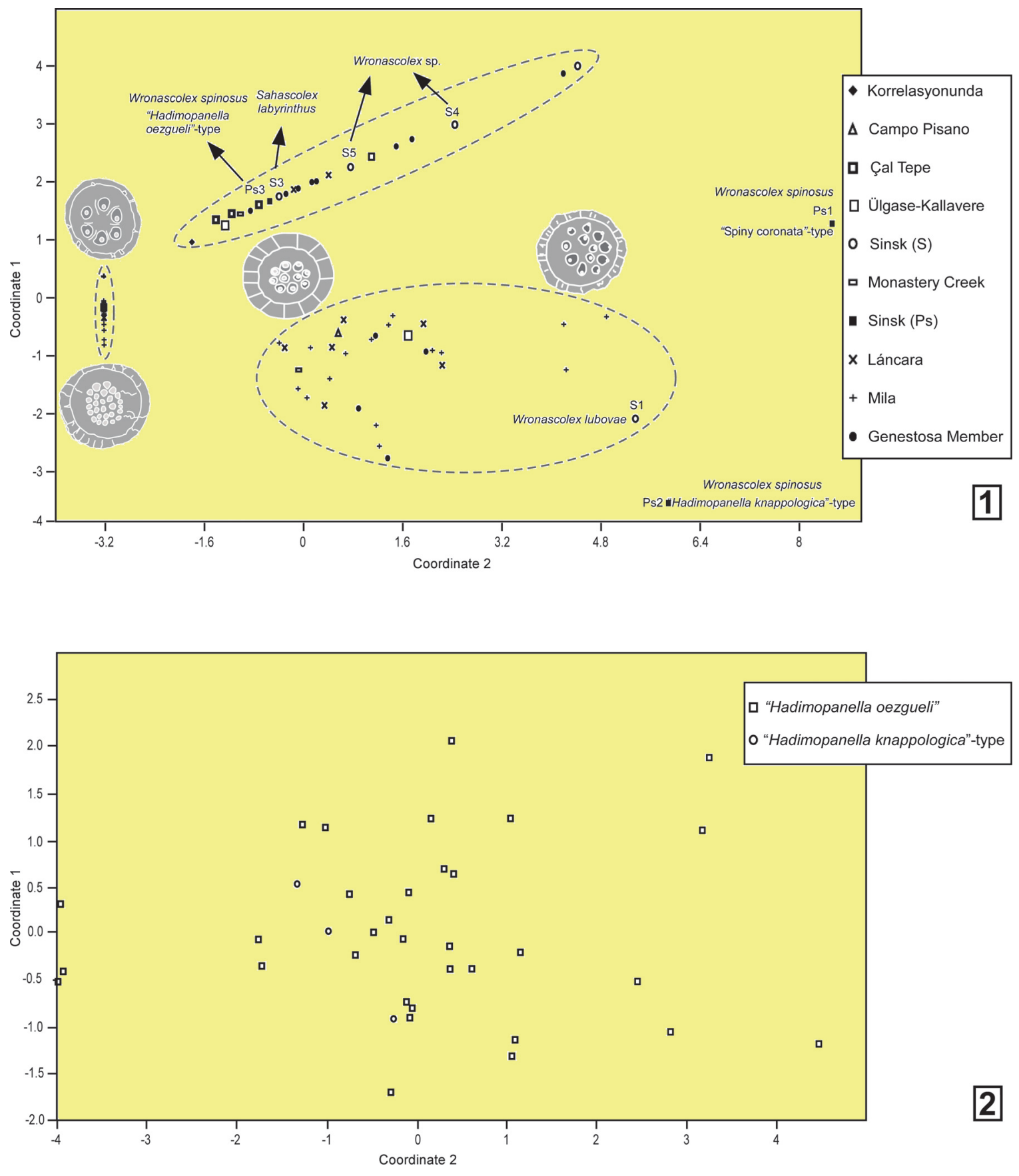

FIGURE 6. (1) Principal-coordinates diagram of dorsal-view sclerites from the Genestosa Member compared with other occurrences of Hadimopanella oezgueli Gedik, 1977 from Gondwana and Siberia. (2) Principal-coordinates diagram of lateral-view sclerites from the Genestosa Member with indication of "Hadimopanella knappologica"-type sclerites.

photypes, whereas one distinct sclerite morphotype occurs in different genera and species, as has been demonstrated in the case of $W$. spinosus, $W$. sp., and S. labyrinthus.

A statistic test of consistency was applied to the above analysis based on ANOSIM (Analysis of Similarities) test. ANOSIM is a non-parametric test to differentiate groups of multivariate data points (Hammer and Harper, 2006). It was applied to the two superclusters (morphotypes) identified above: with 1000 permutations, and using chord, BrayCurtis, Morista, and Euclidean distance measures, the test statistic is consistently high $(R=0.91-0.96)$ and the $p$ value remains $<0.0001$, proving signifi- 


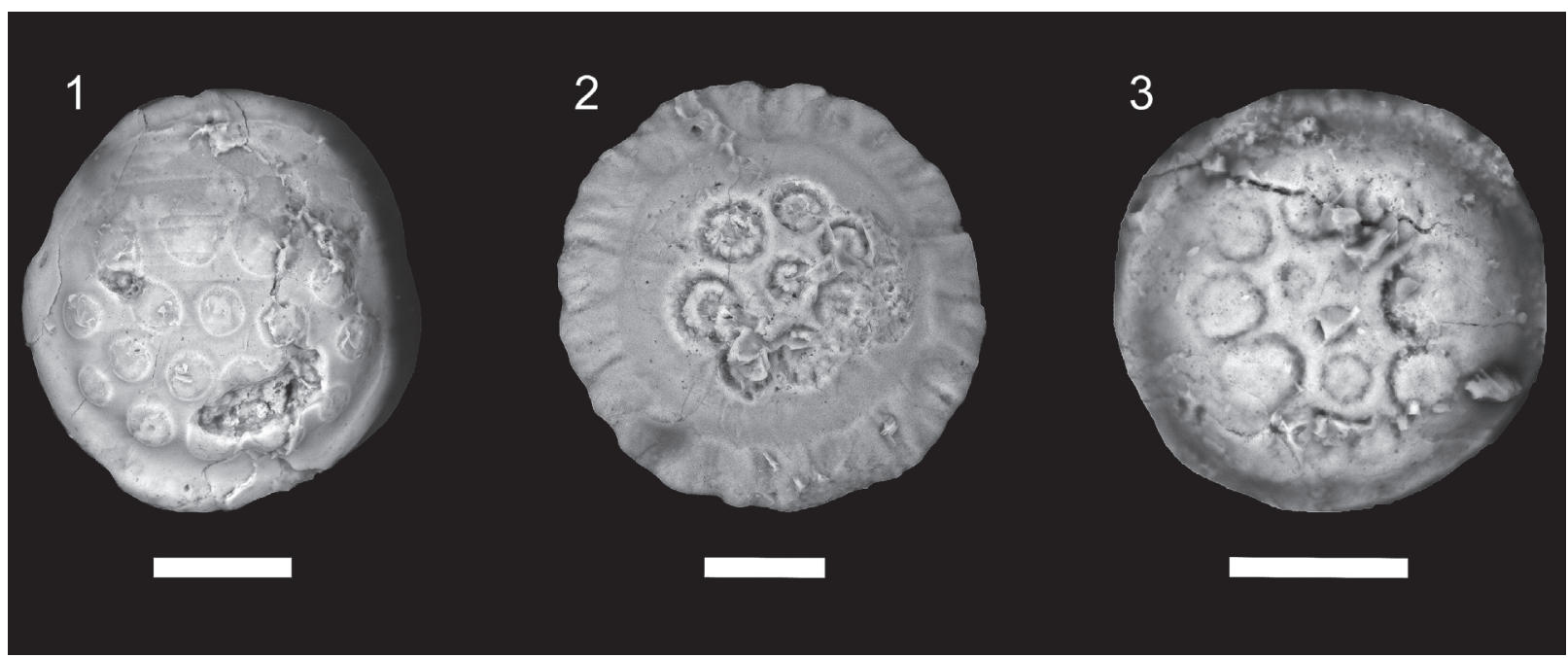

FIGURE 7. (1-3) Dorsal views of sclerites with eroded tubercles; only specimen 2 preserves its original marginal brim. Scale bars equal $50 \mu \mathrm{m}$ (MGM 1134K to MGM 1136K).

cant differences between groupings and thus supporting the result of the cluster analysis.

By contrast, the principal coordinates diagram performed with lateral-view sclerites does not show any distinctive morphotypes (Figure 6.2). In general, all the samples are dispersed in a cloud. Some "Hadimopanella knappologica"-type sclerites may be distinctly identified in this diagram owing to their characteristic flat crest and high number of tubercles (Figure 5.8).

\section{TAPHONOMIC CONSTRAINTS}

Some sclerites display eroded facets, mainly affecting tubercles, whereas others exhibit both tubercles and marginal brim eroded (Figure 7.1-3). Selective abrasion of tubercles could be explained by ultrastructure and growth patterns, as tubercles are easily susceptible to loss in life of palaeoscolecids since they grow by molting. The old cuticles overlying the new ones show tubercles dramatically eroded by friction (Müller and Hinz-Schallreuter, 1993: text figure 14) (Figure 7.2). In addition, eroded tubercles may reflect transport prior to definitive burial, which is consistent with their occurrence in storm-induced deposits.

The presence of chlorites both on the surface and within the Hadimopanella sclerites is well constrained by SEM analysis. The surface is rife with authigenic chlorites displayed in a honey-comb arrangement (Figure 8.1). In broken and corroded specimens, chlorite crystals occur seemingly replacing the original apatite (Figure 8.2 ). In addition, these chlorites also occur occluding internal fissure networks, clearly recognized in SEM by their darker grey color (Figure 8.5). The cross-section of a well-preserved sclerite (Figure 8.3) allows identification of chlorite distribution in a selective way, depending on porosity or cracking in each surface area so that, in BSE analyses, chlorites (recognisable by mapping of $\mathrm{Fe}$ and $\mathrm{Mg}$ in yellow and white, respectively, Figure 8.4), are preferably located covering the tuberculated surface and the base of the marginal brim. In contrast, pristine apatite (see mapping of $\mathrm{P}$ and $\mathrm{Ca}$ elements in turquoise and white, respectively), which could represent the primary biomineral cuticle of the palaeoscolecids (Harvey et al., 2010), forms the surface of the middle surface and the marginal brim. As a result, the preservation after diagenetic mineral replacement can be explained by its nonporous and massive character: the resulted phosphatic parts of the sclerite were less susceptible to be damaged by abrasion and affected by cement occlusion. In Figure 8.6, BSE of a crosscut specimen (see picture by SEM in Figure 8.5 ), has distinct chlorites occluding internal fissures, represented by $\mathrm{Fe}-\mathrm{Al}$ in yellow and white, and original apatite composition, illustrated by $\mathrm{P}-\mathrm{Ca}$ colors (turquoise and white, respectively).

\section{CALM CLAYEY VS ENERGETIC SHELLY SUBSTRATES}

Two types of middle Cambrian limestones have yielded Hadimopanella sclerites in the Cantabrian Mountains: the Barrios facies of the upper Láncara Member (van den Boogaard, 1983) and the interbedded storm-induced limestones of the 

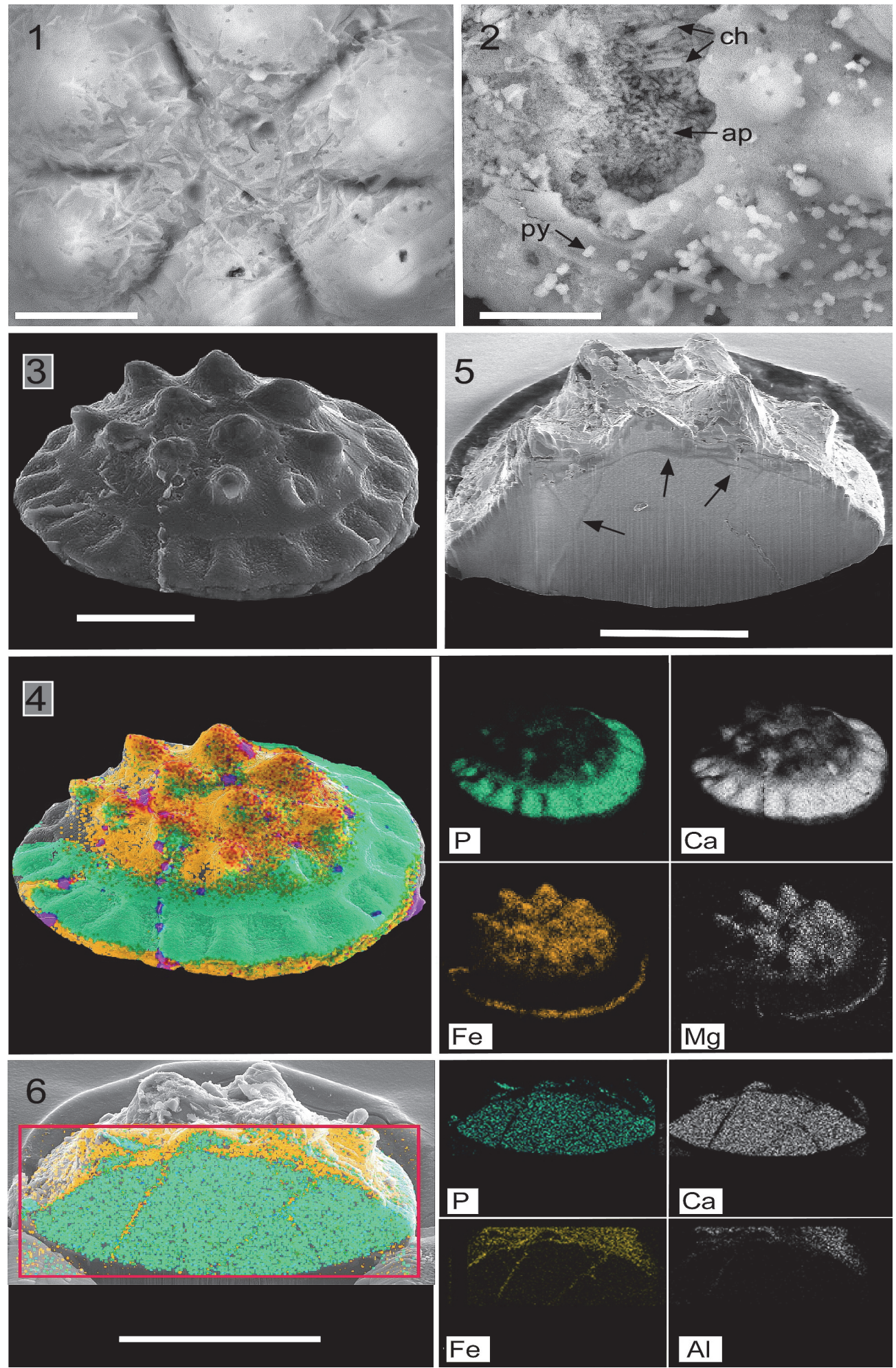

FIGURE 8. Fig. (1) Honey-comb arrangement of chlorites on the top of a sclerite (detail of Figure 5.11) MGM 1128K. (2) Chlorites embedded in the apatite (ap) framework of a corroded sclerite (arrowed) with diagenetic crystals of pyrite (py) and chlorite (ch), MGM 1104K. (3) Complete sclerite, MGM 1137K. (4) BSE analysis of previous sclerite with chlorite arrangement marking porous and fissured areas. (5). Lateral section of sclerite showing fissure network (arrowed), MGM 1138K. (6) BSE analysis of previous sclerite with chlorites occluding the internal fissure network. Scale bars: $1-2$ equal $20 \mu \mathrm{m} ; 3-4$ equal $100 \mu \mathrm{m} ; 5$ equals $40 \mu \mathrm{m} ; 6$ equals $60 \mu \mathrm{m}$. 
overlying Genestosa Member, Oville Formation (this paper).

The Barrios or griotte facies, up to $30 \mathrm{~m}$ thick, consists of centimetre-thick alternations of reddish to purple, nodular and bedded limestone/shale couplets. They represent episodes of shelly carbonate productivity on synsedimentary palaeohighs, finally sealed by the shale-dominated Genestosa Member. Drowning and subsequent transgression of the palaeohighs led to a distinct change in benthic fauna, from echinoderm-rich to trilobite-brachiopod-rich fossil assemblages (Wotte, 2009b). Hadimopanella sclerites were found in the upper part of the Barrios facies in Los Barrios de Luna and Valdoré (Fernández-Remolar, 2001, van den Boogaard 1983) in shelly substrates representative of shoreface environments under persistent wave action (Álvaro et al., 2000; Álvaro and Clausen, 2005; Wotte et al., 2007).

The Genestosa Member, c. 350 m thick, consists of burrowed greenish claystone beds with abundant centimetre- to decimetre-thick carbonate interbeds and nodules, including shelly wackestone-packstone and laminated calcisiltites. Carbonate interbeds provide evidence for episodic storm deposits. The general depositional environment of the Genestosa Member is envisaged as an offshore-dominated, gently northwardly sloping clayey shelf. The platform bordered in the SE with a sandy shoreline that diachronously prograded leading to the onset of sandstone wedge interbeds (e.g., the so-called "simula sandstone"; Zamarreño, 1972). The episodic record of vigorous burrowing, among other factors, allowed sedentary fauna (mainly eocrinoids and sponges) to proliferate. Turbidity was another limiting factor due to the coexistence of autochthonous epibenthic assemblages of normal-eyed and blind trilobites (the socalled conocoryphid biofacies; Álvaro and Vizcaïno, 2003). In bottom conditions of increasing sedimentation rates and turbidity, muds lacking cohesion are easily re-suspended to generate high-turbidity conditions. As a result, mud suspended in water may have greatly reduced the amount of light reaching the seafloor, and dark to dimly lit substrate conditions may be formed.

Errant palaeoscolecids were vagile colonizers of both high-energy shelly substrates (firm carbonate substrates consolidated by early-diagenetic cementation processes, see Zamora et al., 2010) and low-energy clayey substrates (subsequently reworked by tempestites) across the LeonianCaesaraugustan. Their preservation is not dependent on the kind of seafloor, but on taphonomic constraints. Both wave and storm action exerted their influence upon benthic communities and must be considered as primary agents of substrate modification and episodic physical disturbances. Storms generated winnowing leading to shell-bed formation by initiating shelly pavements on an otherwise soft substrate. This distribution resulted in the patchy development of epibenthic multispecies clumps on shell grounds.

\section{DISCUSSION AND CONCLUSIONS}

Sclerites of Hadimopanella oezgueli yielded by the Genestosa limestone interbeds (middle Cambrian) of the Oville Formation (Cantabrian Mountains) show a widespread morphological variability. Variable parameters include the number of dorsal tubercles (a single circle with 2-15 tubercles) and a variable number of central tubercles (even their absence); a variable eccentricity of the tuberculate surface; a variable relative width of the marginal brim, middle, and tuberculated surfaces; and a variable diameter and upper end (acute vs rounded) of dorsal tubercles.

The taxonomic connection between disarticulated sclerites and scleritomes depends on the proper preservation of the former and statistical analyses, like those made in this paper. These allow characterization of parataxonomic diversity in a same stratigraphic level. After statistical comparison with other palaeoscolecidan taxa bearing sclerites of $H$. oezgueli, it is possible to conclude that different ventral-sided sclerites of a same scleritome comprise different (ventral trunk) sclerite morphotypes, whereas one distinct sclerite morphotype occurs in different genera and species. These results confirm in a representative way that the diagnostic features that characterize the parataxon $H$. oezgueli have serious difficulties to establish any (bio)taxonomic classification for palaeoscolecidan (scleritome-based) worms. Therefore, the diagnostic characters of isolated sclerites, such as those of the parataxon $H$. oezgueli, must be not taken into consideration for diagnosing scleritome taxa, and the parataxon $\mathrm{H}$. oezgueli should not be used for (bio) taxonomic purposes.

Two parallel taxonomic classifications are currently applied to palaeoscolecidan complete scleritomes and disarticulated sclerites. Three scleritebased parataxa are formally erected, Milaculum, Hadimopanella and Kaimenella (e.g., Gedik, 1977; Hinz et al., 1990; Müller, 1973; van de Boogaard, 1983), based on specific external ornamentation patterns. By contrast, taxonomy of complete scler- 
itomes (Bengtson, 1985) has been achieved based on partial scleritome. Although the ontogeny of palaeoscolecids is suspected to be complex (Botting et al., 2012; Brock and Cooper, 1993; Topper et al., 2010), the transition from juvenile to adult stages is not characterized by any significant change in the shape or size of sclerites. Only the interspace between single plates gradually increases during the ontogeny because of an incomplete development of cuticular structures (Zhuravlev et al., 2011).

The occurrence of palaeoscolecidan sclerites does not depend on the kind of substrate (clayey vs. shelly) since palaeoscolecids lived on both calm and energetic substrates. By contrast, their abundance is dramatically constrained by taphonomic processes (including occlusion of diagenetic fissures by chlorite) and the possibility of etching extraction.

\section{ACKNOWLEDGEMENTS}

The authors thank the useful revision made by two anonymous referees. This paper is a contribution to projects CGL2010-19491, CGL2013-48877 and GCL2011-24516 from Spanish MINECO and EU-FEDER. J.E. is supported by European Social fund and Ministry of Education Youth and Sport, Czech Republic (Ref.CZ. 1.07/2.3.00/30.0013). S.Z. is funded by a Ramón y Cajal Grant (RYC2012-10576).

\section{REFERENCES}

Abràmoff, M.D., Magalhães, P.J., and Ram, S.J. 2004. Image processing with ImageJ. Biophotonics International, 11(7):36-42.

Álvaro, J.J. 2007. New ellipsocephalid trilobites from the lower Cambrian member of the Láncara Formation, Cantabrian Mountains, northern Spain. Memoirs of the Association of Australasian Palaeontologists, 34:343-355.

Álvaro, J.J. and Clausen, S. 2005. Major geodynamic and sedimentary constraints on the chronostratigraphic correlation of the Lower-Middle Cambrian transition in the western Mediterranean region. Geosciences Journal, 9:145-160.

Álvaro, J.J. and Vizcaïno, D. 2003. The conocoryphid biofacies, a benthic assemblage of normal-eyed and blind trilobites. Special Papers on Palaeontology, 70:127-140.

Álvaro, J.J., Vennin, E., Moreno-Eiris, E., Perejón, A., and Bechstädt, T. 2000. Sedimentary patterns across the Lower-Middle Cambrian transition in the Esla nappe (Cantabrian Mountains, northern Spain). Sedimentary Geology, 137:43-61.
Álvaro, J.J., Zamora, S., Clausen, S., Vizcaïno, D. and Smith, A.B. 2013. The role of abiotic factors in the Cambrian Substrate Revolution: A review from the benthic community replacements of West Gondwana. Earth-Science Reviews, 118:69-82.

Aramburu, C. and García Ramos, J.C. 1993. La sedimentación cambro-ordovícica en la Zona Cantábrica (NO de España). Trabajos de Geología, Universidad de Oviedo, 19:45-73.

Aramburu, C., Truyols, J., Arbizu, M., Méndez-Bedia, I., Zamarreño, I., García-Ramos, J. C., Suárez de Centi, C., and Valenzuela, M. 1992. El Paleozoico Inferior de la Zona Cantábrica. p. 397-422. In Gutiérrez-Marco, J.C., Saavedra, C. and Rábano, I. (eds.), Paleozoico Inferior de Ibero-América, UNEX Press, Mérida.

Bendix-Almgren, S.E. and Peel, J.S. 1988. Hadimopanella from the Lower Cambrian of North Greenland: structure and affinities. Bulletin of the Geological Society of Denmark, 37:83-103.

Bengtson, S. 1977. Early Cambrian button-shaped phosphatic microfossils from the Siberian Platform. Palaeontology, 20:751-762.

Bengtson, S. 1985. Taxonomy of disarticulated fossils. Journal of Paleontology, 59:1350-1358.

Botting, J.P., Muir, L.A., Van Roy, P., Bates, D., and Upton, C. 2012. Diverse Middle Ordovician palaeoscolecidan worms from the Builth-Llandrindod inlier of central Wales. Palaeontology, 55:501-528.

Brock, G.A. and Cooper, B.J. 1993. Shelly fossils from the Early Cambrian (Toyonian) Wirrealpa, Aroona Creek, and Ramsay limestones of South Australia. Journal of Paleontology, 67:758-787.

Clausen, S. and Álvaro, J.J. 2006. Skeletonized microfossils from the Lower-Middle Cambrian transition of the Cantabrian Mountains, northern Spain. Acta Palaeontologica Polonica, 51:223-238.

Conway Morris, S. 1997. The cuticular structure of the 495-Myr-old type species of the fossil worm Palaeascolex, $P$. piscatorum (?Priapulida). Zoological Journal of the Linnean Society, 119:69-82.

Conway Morris, S. and Peel, J.S. 2010. New palaeoscolecidan worms from the Lower Cambrian: Sirius Passet, Latham Shale and Kinzers Shale. Acta Palaeontologica Polonica, 55:141-156.

Conway Morris, S. and Robison, R.A. 1986. Middle Cambrian priapulids and other soft-bodied fossils from Utah and Spain. University of Kansas Paleontological Contributions, 9:1-22.

Elicki, O. 2006. Microbiofacies analysis of Cambrian offshore carbonates from Sardinia (Italy): environment reconstruction and development of a drowning carbonate platform. Carnets de Géologie, 2006:1-26.

Fernández-Remolar, D. 2001. Nota sobre la distribución estratigráfica de Hadimopanella Gedik, 1977 (microescleritos de paleoscolécidos), en el Cámbrico. Revista Española de Micropaleontología, 33:113-121. 
García-Bellido, D.C., Paterson, J.R., and Edgecombe, G.D. 2013. Cambrian palaeoscolecids (Cycloneuralia) from Gondwana and reappraisal of species assigned to Palaeoscolex. Gondwana Research, 24:780-795.

Gedik, I. 1977. Conodont stratigraphy in the Middle Taurus. Bulletin of the Geological Society of Turkey, 20:35-48. (In Turkish)

Gedik, I. 1989. Hadimopanellid biostratigraphy in the Cambrian of the Western Taurids: A new biostratigraphic tool in the subdivision of Cambrian System. Geological Bulletin of Turkey, 32:65-78. (In Turkish)

Gower, J.C. 1966. Some distance properties of latent root and vector methods used in multivariate analysis. Biometrika, 53:325-338.

Hammer, Ø. and Harper, D.A.T. 2006. Paleontological Data Analysis. Blackwell, Oxford, 351 p.

Hammer, M.F., Karafet M.T., Redd A.J., Jarjanazi H., Santachiara-Benerecetti, A.S., Soodyall, H., and Zegura, S.L. 2001. Hierarchical patterns of global human Y-chromosome diversity. Molecular Biology Evolution, 18:1189-1203.

Han, J., Liu, J.N., Zhang, Z.F., Zhang, X.L., and Shu, D.G. 2007a. Trunk ornamentation on the palaeoscolecid worms Cricocosmia and Tabelliscolex from the Early Cambrian Chengjiang deposits of China. Acta Palaeontologica Polonica, 52:423-431.

Han, J., Yang, Y., Zhang, Z.F., Liu, J.N., and Degan, D.G. 2007b. New observations on the palaeoscolecid worm Tylotites petiolaris from the Cambrian Chengjiang Lagerstatte, south China. Paleontological Research, 11:59-69.

Han, J., Zhang, Z.F., Liu, J., and Shu, D.G. 2007c. Evidence of priapulid scavenging from the Early Cambrian Chengjiang deposits, Southern China. Palaios, 22:691-694.

Harvey, T.H.P., Dong, X.P., and Donoghue, P.C.J. 2010. Are palaeoscolecids ancestral ecdysozoans? Evolution \& Development, 12:177-200.

Hinz, I., Kraft, P., Mergl, M., and Müller, K.J. 1990. The problematic Hadimopanella, Kaimenella, Milaculum and Utahphospha identified as sclerites of Palaeoscolecida. Lethaia, 23:217-221.

Hou, X. and Bergström, J. 1994. Palaeoscolecid worms may be nematomorphs rather than annelids. Lethaia, 27:11-17.

Ivantsov, A.Yu. and Wrona, R. 2004. Articulated palaeoscolecid sclerite arrays from the Lower Cambrian of eastern Siberia. Acta Geologica Polonica, 54:1-22.

Ivantsov, A.Yu. and Zhuravlev, A.Yu. 2005. Cephalorhynchs, p. 61-72. In Pomarenko, A.G. (ed.), Unikalnye sinskiye mestonakhozhdeniya rannekembriyskikh organizmov. Trudy Paleontologicheskogo Instituta, Moscow. (In Russian)

Kraft, P. and Mergl, M. 1989. Worm-like fossils (Palaeoscolecida; ?Chaetognatha) from the Lower Ordovician of Bohemia. Sborník geologických vĕd Paleontologie, 30:9-36.
Liñán, E., Perejón, A., and Sdzuy, K. 1993. The LowerMiddle Cambrian stages and stratotypes from the Iberian Peninsula: a revision. Geological Magazine, 130:817-833.

Märss, T. 1988. Early Palaeozoic hadimopanellids of Estonia and Kirgizia (USSR). Proceedings of the Academy of Sciences of the Estonian SSP, Geology, $37: 10-17$.

Müller, K.J. 1973. Milaculum n. gen., ein phosphatisches Mikrofossil aus dem Altpalaeozoikum. Paläontogische Zeitschrift, 47:217-228.

Müller, K.J. and Hinz-Schallreuter, I. 1993. Palaeoscolecid worms from the Middle Cambrian of Australia. Palaeontology, 36:543-592.

Peel, J.S. and Larsen, N.H. 1984. Hadimopanella apicata from the Lower Cambrian of western North Greenland. Rapport Grønlands Geologiske Undersøgelse, 121:89-96.

Perejón, A. and Moreno-Eiris, E. 2003. Arqueociatos del Bilbiliense (Cámbrico Inferior) del manto del Esla, Cordillera Cantábrica, Norte de España. Boletín de la Real Sociedad Española de Historia Natural (Sección Geológica), 98:51-71.

Robison, R.A. 1969. Annelids from the Middle Cambrian Spence Shale of Utah. Journal of Paleontology, 43:1169-1173.

Sarmiento, G.N., Fernández-Remolar, D., and Göncüoglu, C. 2001. Cambrian small shelly fossils from the Çal Tepe Formation, Taurus Mountains, Turkey. Coloquios de Paleontología, 52:117-134.

Sdzuy, K. 1968. Trilobites del Cámbrico Medio de Asturias. Trabajos de Geología, Universidad de Oviedo, $1: 77-135$.

Sdzuy, K. 1995. Acerca del conocimiento actual del Sistema Cámbrico y del límite Cámbrico InferiorMedio, p. 253-263. In Gámez Vintaned, J.A. and Liñán, E. (eds.), La expansión de la vida en el Cámbrico. Institución 'Fernando el Católico', Zaragoza.

Topper, T.P., Brock, G.A., Skovsted, C.B., and Paterson, J.R. 2010. Palaeoscolecid scleritome fragments with Hadimopanella plates from the early Cambrian of South Australia. Geological Magazine, 147:86-97.

Ulrich, E.O. 1878. Observations on fossil annelids and descriptions of some new forms. Journal of the Cincinnati Society of Natural History, 1:87-91.

van den Boogaard, M. 1983. The occurrence of Hadimopanella oezgueli Gedik in the Láncara Formation in NW Spain. Proceedings of the Koninklijde Nederlandse Akademie van Wetenschappen Series $B$, 86:331-341.

van den Boogaard, M. 1988. Some data on Milaculum Müller, 1973. Scripta Geologica, 88:1-25.

van den Boogaard, M. 1989a. A problematic microfossil, Hadimopanella? coronata sp. nov., from the Ordovician of Estonia. Rijksmuseum van Geologie en Mineralogie Series B, 92:179-190.

van den Boogaard, M. 1989b. Isolated tubercles of some Palaeoscolecida. Scripta Geologica, 90:1-12. 
van der Meer Mohr, C.G. 1969. The stratigraphy of the Cambrian Láncara Formation between the Luna river and the Esla river in the Cantabrian Mountains, Spain. Leidse Geologische Mededelingen, 43:233316.

Ward, J.H. 1963. Hierarchical grouping to optimize an objective function. Journal of the American Statistical Association, 58:236-244.

Whittard, W.F. 1953. Palaeoscolex piscatorum gen. et sp. nov., a worm from the Tremadocian of Shropshire. Quarterly Journal of the Geological Society of London, 109:125-35.

Wills, M.A., Gerber, S., Ruta, M., and Hughes, M. 2012. The disparity of priapulid, archaeopriapulid and palaeoscolecid worms in the light of new data. Journal of Evolutionary Biology, 25:2056-2076.

Wotte, T. 2006. New Middle Cambrian molluscs from the Láncara Formation of the Cantabrian Mountains (north-western Spain). Revista Española de Paleontología, 21:145-158.

Wotte, T. 2009a. The youngest cambroclaves: Cambroclavus absonus from the Middle Cambrian of the Cantabrian zone (northwest Spain). Journal of Paleontology, 83:128-134.

Wotte, T. 2009b. Re-interpretation of a Lower-Middle Cambrian West Gondwanan ramp depositional system: a case study from the Cantabrian Zone (NW Spain). Facies, 55:473-487.

Wotte, T. and Mergl, M. 2007. Brachiopods from the Lower-Middle Cambrian Láncara Formation of the Cantabrian Mountains, Northwest Spain. Memoirs of the Association of Australasian Palaeontologists, 33:101-122.
Wotte, T., Álvaro, J.J., Shields, G.A., Brasier, M., and Veizer, J. 2007. C-, O- and Sr-isotope stratigraphy across the Lower-Middle Cambrian transition of the Cantabrian Mountains (Spain) and the Montagne Noire (France), West Gondwana. Palaeogeography, Palaeoclimatology, Palaeoecology, 256:47-70.

Wrona, R. 1982. Early Cambrian phosphatic microfossils from southern Spitsbergen (Horsund region). Palaeontologia Polonica, 43:9-16.

Wrona, R. 1987. Cambrian microfossil Hadimopanella Gedik from glacial erratics in West Antarctica. In Gazdzicki, A. (ed.), Palaeontological Results of the Polish Antarctic Expeditions, Part I. Palaeontologia Polonica, 49:37-48.

Wrona, R. and Hamdi, B. 2001. Palaeoscolecid sclerites from the Upper Cambrian Mila Formation of the Shahmirzad section, Alborz Mountains, northern Iran. Acta Geologica Polonica, 51:101-107.

Zamarreño, I. 1972. Las litofacies carbonatadas del Cámbrico de la Zona Cantábrica (NW España) y su distribución paleogeográfica. Trabajos Geológicos, Universidad de Oviedo, 5:1-118.

Zamora, S., Clausen, S., Álvaro, J.J., and Smith, A.B. 2010. Pelmatozoan echinoderms as colonizers of carbonate firmgrounds in mid-Cambrian high energy environments. Palaios, 25:764-768.

Zhang, X.G. and Pratt, B.R. 1996. Early Cambrian palaeoscolecid cuticles from Shaanxi, China. Journal of Paleontology, 70:275-279.

Zhuravlev, A.Yu., Gámez Vintaned, J.A., and Liñán, E. 2011. The Palaeoscolecida and the evolution of the Ecdysozoa. Palaeontographica Canadiana, 31:177204. 
APPENDIX 1.

Absolute measures of Hadimopanella oezgueli dorsal-view sclerites from the Genestosa Member (PDF only).

\section{APPENDIX 2.}

Absolute measures of Hadimopanella oezgueli dorsal-view sclerites from other published papers (PDF only). 
APPENDIX 3.

Dorsal relationships used in the establishment of morphotypes of Hadimopanella oezgueli from the Genestosa Member and other occurrences from published reports.

\begin{tabular}{|c|c|c|c|c|c|c|c|c|c|c|}
\hline \multirow[b]{2}{*}{$\begin{array}{l}\text { Dorsal } \\
\text { name }\end{array}$} & \multicolumn{3}{|c|}{ Diameter relation } & \multirow{2}{*}{$\begin{array}{c}\text { Diameter } \\
\text { base } \\
\text { surface }\end{array}$} & \multirow{2}{*}{$\begin{array}{c}\text { Diameter } \\
\text { tuberculated } \\
\text { surface }\end{array}$} & \multirow{2}{*}{$\begin{array}{l}\text { Eccentric } \\
\text { deviation } \\
\quad(e d) \\
\text { ed/dmax }\end{array}$} & \multirow[b]{2}{*}{$\begin{array}{c}\text { notubercles }^{\circ} \\
\text { dme }\end{array}$} & \multicolumn{2}{|c|}{ Feature of tubercles } & \multirow[b]{2}{*}{$\begin{array}{c}\text { ø largest } \\
\text { tubercle/ } \\
\text { smallest } \\
\text { tubercle }\end{array}$} \\
\hline & $\begin{array}{l}\text { Dme I } \\
\text { dme }\end{array}$ & $\begin{array}{c}\text { Dme- } \\
\text { d'me/D }\end{array}$ & $d^{\prime}-d / D$ & & & & & $\begin{array}{c}\varnothing \text { largest } \\
\text { tubercle } / \varnothing \\
\text { tip }\end{array}$ & $\begin{array}{c}\varnothing \text { smallest } \\
\text { tubercle } / \varnothing \\
\text { tip }\end{array}$ & \\
\hline HD-18-01 & 1.991 & 0.247 & 0.251 & 1.036 & 1.125 & 0.006 & 0.114 & 2.160 & 2.906 & 1.705 \\
\hline HD-3-01 & 1.390 & 0.146 & 0.135 & 1.050 & 1.235 & 0.090 & 0.129 & 4.460 & 3.215 & 1.631 \\
\hline HD-2-01 & 1.471 & 0.143 & 0.177 & 1.055 & 1.181 & 0.084 & 0.113 & 4.069 & 2.132 & 2.092 \\
\hline HD-34-01 & 1.839 & 0.196 & 0.261 & 1.042 & 1.294 & 0.103 & 0.000 & 3.712 & 2.208 & 2.157 \\
\hline HD-33-01 & 1.681 & 0.187 & 0.218 & 1.022 & 1.120 & 0.097 & 0.129 & 2.187 & 2.550 & 2.047 \\
\hline HD-5-01 & 2.088 & 0.276 & 0.245 & 1.111 & 1.182 & 0.238 & 0.098 & 6.153 & 4.300 & 1.951 \\
\hline HD-7-01 & 1.748 & 0.195 & 0.233 & 1.094 & 1.131 & 0.122 & 0.135 & 7.036 & 4.047 & 1.156 \\
\hline HD-21-01 & 1.460 & 0.096 & 0.219 & 1.046 & 1.082 & 0.082 & 0.311 & - & - & 1.602 \\
\hline HD-22-01 & 1.621 & 0.194 & 0.189 & 1.147 & 1.015 & 0.094 & 0.181 & - & - & 1.270 \\
\hline H1-01 & 1.558 & 0.155 & 0.203 & 1.109 & 1.057 & 0.083 & 0.117 & - & - & 2.800 \\
\hline H26-01 & 1.589 & 0.154 & 0.216 & 1.026 & 1.142 & 0.090 & 0.108 & - & - & 2.581 \\
\hline HD-9-01 & 1.644 & 0.164 & 0.228 & 1.086 & 1.196 & 0.069 & 0.124 & - & - & 1.581 \\
\hline HD-29-01 & 1.612 & 0.088 & 0.291 & 1.079 & 1.183 & 0.065 & - & - & - & 1.376 \\
\hline HD-12-01 & 1.524 & 0.100 & 0.244 & 1.028 & 1.236 & 0.052 & 0.175 & - & - & 1.967 \\
\hline $\mathrm{H} 25-01$ & 1.690 & 0.108 & 0.300 & 1.187 & 1.133 & 0.220 & - & - & - & 1.455 \\
\hline HD-10-01 & 1.607 & 0.167 & 0.211 & 1.091 & 1.210 & 0.089 & - & - & - & - \\
\hline HD-28-01 & 2.177 & 0.169 & 0.372 & 1.181 & 1.081 & 0.143 & 0.178 & - & - & 1.486 \\
\hline HD-24-01 & 1.780 & 0.123 & 0.315 & 1.089 & 1.100 & 0.128 & 0.136 & - & - & 1.766 \\
\hline HD-32-01 & 1.672 & 0.151 & 0.251 & 1.254 & 1.029 & 0.127 & - & - & - & 1.005 \\
\hline HD-39-01 & 1.672 & 0.113 & 0.163 & 1.254 & 1.029 & 0.126 & - & - & - & 1.070 \\
\hline HD-36-01 & 1.781 & 0.203 & 0.235 & 1.091 & 1.143 & 0.044 & - & - & - & 2.180 \\
\hline HD-1-01 & 1.681 & 0.082 & 0.323 & 1.109 & 1.038 & 0.048 & - & - & - & - \\
\hline HD-35-01 & 1.888 & 0.279 & 0.192 & 1.042 & 1.059 & 0.041 & 0.084 & 2.698 & 4.380 & 1.512 \\
\hline HD-14-01 & 1.369 & 0.065 & 0.205 & 1.187 & 1.267 & 0.032 & 0.084 & 4.002 & 2.415 & 1.141 \\
\hline HD-17-01 & 2.241 & 0.299 & 0.255 & 1.038 & 1.039 & 0.052 & 0.096 & 4.639 & 2.549 & 2.854 \\
\hline HD-15-01 & 1.576 & 0.121 & 0.245 & 1.047 & 1.158 & 0.055 & 0.107 & 6.631 & 3.336 & 2.369 \\
\hline $\mathrm{H} 27-01$ & 1.611 & 0.216 & 0.164 & 1.016 & 1.381 & 0.052 & - & 3.258 & 1.611 & 4.403 \\
\hline HD-4-01 & 2.404 & 0.314 & 0.270 & 1.074 & 1.172 & 0.049 & 0.128 & 2.264 & 1.756 & 1.658 \\
\hline HD-19-01 & 2.019 & 0.267 & 0.238 & 1.119 & 1.131 & 0.057 & 0.107 & 2.799 & 4.080 & 1.305 \\
\hline H10-01 & 1.880 & 0.283 & 0.185 & 1.034 & 1.023 & 0.062 & 0.146 & 2.614 & 2.177 & 1.471 \\
\hline H19-01 & 2.302 & 0.334 & 0.231 & 1.091 & 1.145 & 0.062 & 0.120 & 3.130 & 2.408 & 1.756 \\
\hline HD-41-01 & 1.999 & 0.242 & 0.258 & 1.074 & 1.150 & 0.022 & - & - & - & - \\
\hline HD-40-01 & 2.080 & 0.203 & 0.317 & 1.121 & 1.103 & 0.017 & 0.320 & - & - & 1.222 \\
\hline Mila1 & 1.690 & 0.221 & 0.187 & 1.086 & 1.113 & 0.114 & 0.032 & 5.645 & - & - \\
\hline Mila2 & 1.577 & 0.129 & 0.236 & 1.024 & 1.185 & 0.056 & 0.110 & 2.665 & 4.732 & 1.348 \\
\hline Mila3 & 1.960 & 0.256 & 0.234 & 1.063 & 1.083 & 0.026 & 0.057 & 4.167 & 3.231 & 1.216 \\
\hline Mila4 & 2.153 & 0.221 & 0.314 & 1.115 & 1.134 & 0.288 & 0.071 & 3.573 & 2.609 & 1.128 \\
\hline
\end{tabular}




\begin{tabular}{|c|c|c|c|c|c|c|c|c|c|c|}
\hline Mila5 & 1.959 & 0.247 & 0.243 & 1.123 & 1.090 & 0.140 & 0.106 & 3.583 & - & - \\
\hline Mila6 & 1.651 & 0.326 & 0.069 & 1.051 & 1.105 & 0.165 & 0.106 & 2.677 & 3.705 & 1.226 \\
\hline Mila7 & 1.665 & 0.209 & 0.190 & 1.032 & 1.087 & 0.136 & 0.049 & 2.688 & - & - \\
\hline Mila8 & 1.820 & 0.289 & 0.162 & 1.027 & 1.096 & 0.174 & 0.065 & 5.354 & - & - \\
\hline Mila9 & 1.730 & 0.294 & 0.129 & 1.161 & 1.034 & 0.240 & 0.065 & 3.379 & - & - \\
\hline Mila10 & 1.812 & 0.280 & 0.168 & 1.320 & 1.197 & 0.237 & 0.054 & 3.873 & - & - \\
\hline Mila11 & 1.678 & 0.111 & 0.293 & 1.110 & 1.113 & 0.122 & 0.128 & 8.379 & - & - \\
\hline Mila12 & 1.602 & 0.251 & 0.125 & 1.044 & 1.104 & 0.160 & 0.099 & 3.896 & - & - \\
\hline $\begin{array}{l}\text { Ülgase- } \\
\text { Kallavere1 }\end{array}$ & 1.566 & 0.158 & 0.203 & 1.093 & 1.050 & 0.164 & 0.024 & - & - & 1.338 \\
\hline $\begin{array}{l}\text { Ülgase- } \\
\text { Kallavere2 }\end{array}$ & 1.652 & 0.153 & 0.242 & 1.086 & 1.074 & 0.041 & 0.054 & 2.247 & - & - \\
\hline $\begin{array}{l}\text { Ülgase- } \\
\text { Kallavere3 }\end{array}$ & 1.563 & 0.197 & 0.163 & 1.192 & 1.281 & 0.118 & 0.044 & 4.057 & 2.829 & 1.230 \\
\hline $\begin{array}{l}\text { Ülgase- } \\
\text { Kallavere4 }\end{array}$ & 1.524 & 0.186 & 0.157 & 1.059 & 1.047 & 0.075 & 0.049 & 4.907 & - & - \\
\hline $\begin{array}{l}\text { Ülgase- } \\
\text { Kallavere5 }\end{array}$ & 1.398 & 0.217 & 0.068 & 1.081 & 1.038 & 0.078 & 0.058 & - & - & 1.291 \\
\hline Láncara1 & 1.657 & 0.192 & 0.205 & 1.019 & 1.156 & 0.110 & 0.119 & 2.362 & 1.766 & 1.994 \\
\hline Láncara2 & 1.680 & 0.191 & 0.214 & 1.123 & 1.025 & 0.023 & 0.089 & 2.991 & 2.214 & 1.770 \\
\hline Láncara3 & 1.865 & 0.194 & 0.270 & 1.022 & 1.127 & 0.071 & 0.112 & 0.000 & - & 1.664 \\
\hline Láncara4 & 1.715 & 0.226 & 0.191 & 1.159 & 1.007 & 0.055 & 0.100 & 3.332 & 1.976 & 1.431 \\
\hline Láncara5 & 1.613 & 0.197 & 0.184 & 1.173 & 1.014 & 0.012 & 0.060 & 2.220 & 3.406 & 1.197 \\
\hline Láncara6 & 1.639 & 0.262 & 0.128 & 1.153 & 1.089 & 0.067 & 0.020 & 4.227 & 3.677 & 1.048 \\
\hline Láncara7 & 1.425 & 0.169 & 0.129 & 1.067 & 1.148 & 0.078 & 0.052 & 3.548 & - & - \\
\hline Láncara8 & 1.291 & 0.110 & 0.115 & 1.455 & 1.367 & 0.087 & 0.059 & 4.441 & 2.636 & 1.508 \\
\hline Láncara9 & 1.681 & 0.249 & 0.156 & 1.260 & 1.110 & 0.060 & 0.102 & 4.083 & - & - \\
\hline Sinsk S1 & 1.557 & 0.218 & 0.139 & 1.126 & 1.054 & 0.126 & 0.178 & 6.582 & 5.881 & 1.506 \\
\hline Sinsk S2 & 1.314 & 0.121 & 0.118 & 1.094 & 1.054 & 0.079 & 0.289 & 8.637 & - & - \\
\hline Sinsk S3 & 1.387 & 0.089 & 0.190 & 1.059 & 1.063 & 0.086 & 0.316 & 3.258 & - & - \\
\hline Sinsk S4 & 1.874 & 0.203 & 0.263 & 1.208 & 1.265 & 0.255 & 0.189 & 6.426 & - & - \\
\hline Sinsk S5 & 1.949 & 0.189 & 0.298 & 1.110 & 1.105 & 0.026 & 0.214 & 4.521 & - & - \\
\hline $\begin{array}{l}\text { Korrelasyon } \\
\text { unda1 }\end{array}$ & 1.681 & 0.224 & 0.181 & 1.069 & 1.104 & 0.044 & 0.043 & 1.550 & - & - \\
\hline Sinsk Ps1 & 1.804 & 0.312 & -0.134 & 1.037 & 1.093 & 0.727 & 0.190 & 11.080 & 4.179 & 1.157 \\
\hline Sinsk Ps2 & 1.565 & 0.273 & -0.088 & 1.039 & 1.263 & 0.095 & 0.257 & 6.338 & 7.454 & 1.804 \\
\hline Sinks Ps3 & 1.817 & 0.227 & -0.223 & 1.009 & 1.073 & 2.192 & 0.146 & 2.898 & - & - \\
\hline $\begin{array}{l}\text { Monastery } \\
\text { Greek1 }\end{array}$ & 0.745 & 0.185 & 0.168 & 1.142 & 1.224 & 0.110 & 0.437 & 2.164 & 2.630 & 1.200 \\
\hline $\begin{array}{l}\text { Monastery } \\
\text { Greek2 }\end{array}$ & 0.563 & 0.956 & 0.000 & 1.098 & 1.096 & 0.019 & 0.163 & 2.463 & - & - \\
\hline $\begin{array}{l}\text { Campo } \\
\text { Pisano }\end{array}$ & 1.068 & 0.318 & 0.179 & 1.071 & 1.070 & 0.272 & 0.208 & 3.171 & 2.090 & 1.654 \\
\hline Çal Tepe 1 & 0.637 & 0.158 & 0.028 & 1.139 & 1.058 & 0.012 & - & 2.166 & - & - \\
\hline Çal Tepe 2 & 0.886 & 0.158 & 0.243 & 1.103 & 1.095 & 0.014 & 0.180 & 2.308 & - & - \\
\hline Çal Tepe 3 & 0.896 & 0.242 & 0.167 & 1.116 & 1.065 & 0.076 & 0.115 & 2.851 & - & - \\
\hline
\end{tabular}


BARRAGÁN ET AL.: CAMBRIAN SCLERITES

APPENDIX 4.

Absolute measures of Hadimopanella oezgueli lateral-view sclerites from the Genestosa Member.

\begin{tabular}{|c|c|c|c|c|c|c|c|c|c|c|}
\hline Lateral name & ht & $\mathbf{h}$ & h1 & h2 & h3 & d & $r$ & $\alpha 1$ & $\alpha 2$ & $\alpha 3$ \\
\hline H38-01 & 55.671 & 40.523 & 11.654 & 12.266 & 16.603 & 138.81 & 69.405 & 30.583 & 48.013 & 50.711 \\
\hline $\mathrm{H} 29-01$ & 73.037 & 61.696 & 16.302 & 13.993 & 31.401 & 139.681 & 69.8405 & 56.564 & 52.5 & 39.145 \\
\hline H13-01 & 51.809 & 42.183 & 9.01 & 17.998 & 15.175 & 129.416 & 64.708 & 36.858 & 36.417 & 44.36 \\
\hline H32-01 & 60.671 & 37.346 & 13.414 & 9.935 & 13.997 & 140.827 & 70.4135 & 47.757 & 36.031 & - \\
\hline $\mathrm{H} 21-01$ & 64.839 & 47.617 & 11.099 & 20.12 & 16.398 & 135.281 & 67.6405 & 38.515 & 35.538 & 40.343 \\
\hline H9-01 & 73.868 & 45.555 & 13.951 & 11.46 & 20.144 & 123.545 & 61.7725 & 45.335 & 40.432 & 34.695 \\
\hline H30-01 & 79.495 & 65.154 & 17.624 & 22.536 & 24.994 & 173.338 & 86.669 & 48.93 & 42.057 & 69.391 \\
\hline H26-01 & 78.061 & 69.614 & 22.138 & 14.271 & 33.205 & 153.826 & 76.913 & 46.494 & 55.717 & 70.925 \\
\hline $\mathrm{H} 25-01$ & 63.85 & 49.856 & 16.617 & - & 33.239 & 146.276 & 73.138 & 44.66 & - & 42.272 \\
\hline H6-01 & 66.935 & 57.088 & 19.515 & 16.602 & 20.971 & 173.887 & 86.9435 & 40.173 & 40.024 & 61.048 \\
\hline H19-01 & 72.589 & 52.088 & 16.398 & 14.357 & 21.333 & 149.498 & 74.749 & 48.013 & 39.601 & 60.893 \\
\hline H23-01 & 74.558 & 62.272 & 18.843 & 14.351 & 29.078 & 158.569 & 79.2845 & 43.615 & 44.298 & 54.083 \\
\hline H1-01 & 78.031 & 55.29 & 29.089 & 11.042 & 15.159 & 168.057 & 84.0285 & 33.174 & 31.589 & 51.099 \\
\hline H20-01 & 48.381 & 37.305 & 14.348 & 7.374 & 15.583 & 166.076 & 83.038 & 31.19 & 26.453 & 30.41 \\
\hline H12-01 & 59.917 & 43.498 & 20.521 & 11.898 & 11.079 & 135.442 & 67.721 & 48.197 & 34.088 & 53.797 \\
\hline H3-01 & 65.257 & 55.409 & 18.876 & 18.888 & 17.645 & 176.173 & 88.0865 & 37.81 & 39.168 & 61.948 \\
\hline H34-01 & 66.006 & 54.938 & 16.813 & 21.312 & 16.813 & 161.535 & 80.7675 & 43.027 & 40.772 & 66.46 \\
\hline H31-01 & 65.6525 & 58.436 & 24.717 & 11.609 & 22.11 & 142.863 & 71.4315 & 50.964 & 46.97 & 60.962 \\
\hline H8-01 & 76.307 & 61.14 & 23.393 & 16.374 & 21.373 & 164.154 & 82.077 & 48.166 & 50.606 & 61.126 \\
\hline H10-01 & 48.783 & 48.783 & 17.217 & 5.74 & 25.826 & 158.711 & 79.3555 & 40.692 & 31.834 & 33.532 \\
\hline H28-01 & 51.557 & 38.738 & 11.067 & - & 27.671 & 115.131 & 57.5655 & 45.533 & 25.37 & 56.872 \\
\hline $\mathrm{H} 24-01$ & 76.744 & 58.684 & 20.144 & 8.574 & 29.966 & 156.628 & 78.314 & 39.983 & 34.176 & 34.176 \\
\hline H18-01 & 50.885 & 34.471 & 12.72 & 4.922 & 16.829 & 121.056 & 60.528 & 42.663 & 42.879 & 76.061 \\
\hline HP-3-01 & 60.786 & 50.08 & 18.916 & 12.896 & 18.268 & 150.822 & 75.411 & 49.7 & 48.747 & 41.174 \\
\hline HP-4-01 & 76.969 & 54.951 & 21.444 & - & 33.507 & 174.356 & 87.178 & 32.295 & - & 51.289 \\
\hline HP-5-01 & 53.484 & 39.921 & 10.492 & 9.085 & 20.344 & 132.091 & 66.0455 & 38.074 & - & 65.486 \\
\hline HP-6-01 & 53.961 & 42.709 & 10.486 & 5.964 & 26.259 & 114.546 & 57.273 & 47.85 & - & 69.391 \\
\hline HP-7-01 & 69.182 & 52.483 & 15.339 & 16.526 & 20.618 & 151.992 & 75.996 & 39.245 & 53.051 & 62.488 \\
\hline HP-9-01 & 48.564 & 34.506 & 9.713 & 8.928 & 15.865 & 117.862 & 58.931 & 35.191 & 32.475 & 63.258 \\
\hline HP-10-01 & 51.82 & 40.049 & 11.26 & 9.59 & 19.199 & 136.146 & 68.073 & 32.262 & 62.79 & 74.363 \\
\hline HP-11-01 & 52.927 & 41.419 & 9.974 & 10.096 & 21.349 & 113.808 & 56.904 & 46.231 & 47.778 & 68.091 \\
\hline HP-12-01 & 61.112 & 43.366 & 17.431 & 6.8 & 19.135 & 151.663 & 75.8315 & 28.955 & 40.488 & 56.066 \\
\hline HP-13-01 & 76.903 & 57.684 & 17.772 & 12.534 & 27.378 & 180.253 & 90.1265 & 36.457 & 38.412 & 50.236 \\
\hline HP-14-01 & 66.193 & 52.13 & 17.699 & 13.458 & 20.973 & 154.712 & 77.356 & 44.412 & 35.578 & 43.832 \\
\hline HP-15-01 & 47.047 & 35.028 & 8.185 & 13.032 & 13.811 & 116.204 & 58.102 & 50.528 & 44.297 & 67.655 \\
\hline HP-16-01 & 74.815 & 57.051 & 13.669 & 13.28 & 30.102 & 152.205 & 76.1025 & 42.346 & 47.041 & 62.045 \\
\hline
\end{tabular}




\section{APPENDIX 5.}

Lateral relationships of Hadimopanella oezgueli from the Genestosa Member used for statistical analyses.

\begin{tabular}{|c|c|c|c|c|c|c|c|c|}
\hline \multirow[b]{2}{*}{ Nombre pefil } & \multicolumn{3}{|c|}{ Height relationship } & \multirow{2}{*}{$\begin{array}{c}\text { Radius } \\
\text { relationship } \\
\mathrm{r} / \mathrm{h}\end{array}$} & \multicolumn{3}{|c|}{ Slope relationship } & \multirow{2}{*}{$\begin{array}{c}\text { Features tubercles } \\
\text { base/tip }\end{array}$} \\
\hline & $\mathrm{h} / \mathrm{h} 1$ & $\mathrm{~h} / \mathrm{h} 2$ & $\mathrm{~h} / \mathrm{h} 3$ & & $\operatorname{tg} \alpha 1$ & $\operatorname{tg} \alpha 2$ & $\operatorname{tg} \alpha 3$ & \\
\hline H38-01 & 3.477 & 3.304 & 2.441 & 1.713 & 0.591 & 1.111 & 1.222 & 0.324 \\
\hline $\mathrm{H} 29-01$ & 3.785 & 4.409 & 1.965 & 1.132 & 1.515 & 1.303 & 0.814 & 0.242 \\
\hline $\mathrm{H} 13-01$ & 4.682 & 2.344 & 2.780 & 1.534 & 0.750 & 0.738 & 0.978 & 0.407 \\
\hline H32-01 & 2.784 & 3.759 & 2.668 & 1.885 & 1.101 & 0.727 & - & 0.308 \\
\hline $\mathrm{H} 21-01$ & 4.290 & 2.367 & 2.904 & 1.421 & 0.796 & 0.714 & 0.849 & 0.600 \\
\hline H9-01 & 3.265 & 3.975 & 2.261 & 1.356 & 1.012 & 0.852 & 0.692 & 0.318 \\
\hline H30-01 & 3.697 & 2.891 & 2.607 & 1.330 & 1.148 & 0.902 & 2.659 & 0.318 \\
\hline $\mathrm{H} 26-01$ & 3.145 & 4.878 & 2.096 & 1.105 & 1.054 & 1.467 & 2.892 & 0.121 \\
\hline $\mathrm{H} 25-01$ & 3.000 & 0.000 & 1.500 & 1.467 & 0.988 & 0.000 & 0.909 & 0.180 \\
\hline $\mathrm{H} 6-01$ & 2.925 & 3.439 & 2.722 & 1.523 & 0.844 & 0.840 & 1.808 & 0.412 \\
\hline H19-01 & 3.176 & 3.628 & 2.442 & 1.435 & 1.111 & 0.827 & 1.796 & 0.195 \\
\hline H23-01 & 3.305 & 4.339 & 2.142 & 1.273 & 0.953 & 0.976 & 1.381 & 0.201 \\
\hline H1-01 & 1.901 & 5.007 & 3.647 & 1.520 & 0.654 & 0.615 & 1.239 & 0.311 \\
\hline $\mathrm{H} 20-01$ & 2.600 & 5.059 & 2.394 & 2.226 & 0.605 & 0.498 & 0.587 & 0.277 \\
\hline $\mathrm{H} 12-01$ & 2.120 & 3.656 & 3.926 & 1.557 & 1.118 & 0.677 & 1.366 & 0.425 \\
\hline H3-01 & 2.935 & 2.934 & 3.140 & 1.590 & 0.776 & 0.815 & 1.877 & 0.379 \\
\hline H34-01 & 3.268 & 2.578 & 3.268 & 1.470 & 0.933 & 0.862 & 2.295 & 0.537 \\
\hline H31-01 & 2.364 & 5.034 & 2.643 & 1.222 & 1.233 & 1.071 & 1.801 & 0.279 \\
\hline H8-01 & 2.614 & 3.734 & 2.861 & 1.342 & 1.117 & 1.218 & 1.813 & 0.215 \\
\hline $\mathrm{H} 10-01$ & 2.833 & 8.499 & 1.889 & 1.627 & 0.860 & 0.621 & 0.663 & 0.192 \\
\hline $\mathrm{H} 28-01$ & 3.500 & 0.000 & 1.400 & 1.486 & 1.019 & 0.474 & 1.532 & 0.178 \\
\hline $\mathrm{H} 24-01$ & 2.913 & 6.844 & 1.958 & 1.335 & 0.839 & 0.679 & 0.679 & 0.311 \\
\hline H18-01 & 2.710 & 7.003 & 2.048 & 1.756 & 0.922 & 0.929 & 4.029 & 0.309 \\
\hline HP-3-01 & 2.647 & 3.883 & 2.741 & 1.506 & 1.179 & 1.140 & 0.875 & 0.395 \\
\hline HP-4-01 & 2.563 & 0.000 & 1.640 & 1.586 & 0.632 & 0.000 & 1.248 & 0.091 \\
\hline HP-5-01 & 3.805 & 4.394 & 1.962 & 1.654 & 0.783 & 0.000 & 2.193 & 0.227 \\
\hline HP-6-01 & 4.073 & 7.161 & 1.626 & 1.341 & 1.105 & 0.000 & 2.659 & 0.154 \\
\hline HP-7-01 & 3.422 & 3.176 & 2.545 & 1.448 & 0.817 & 1.330 & 1.920 & 0.172 \\
\hline HP-9-01 & 3.553 & 3.865 & 2.175 & 1.708 & 0.705 & 0.636 & 1.985 & 0.172 \\
\hline HP-10-01 & 3.557 & 4.176 & 2.086 & 1.700 & 0.631 & 1.945 & 3.573 & 0.214 \\
\hline HP-11-01 & 4.153 & 4.103 & 1.940 & 1.374 & 1.044 & 1.102 & 2.486 & 0.212 \\
\hline HP-12-01 & 2.488 & 6.377 & 2.266 & 1.749 & 0.553 & 0.854 & 1.486 & 0.336 \\
\hline HP-13-01 & 3.246 & 4.602 & 2.107 & 1.562 & 0.739 & 0.793 & 1.202 & 0.385 \\
\hline HP-14-01 & 2.945 & 3.874 & 2.486 & 1.484 & 0.980 & 0.715 & 0.960 & 0.201 \\
\hline HP-15-01 & 4.280 & 2.688 & 2.536 & 1.659 & 1.214 & 0.976 & 2.433 & 0.257 \\
\hline HP-16-01 & 4.174 & 4.296 & 1.895 & 1.334 & 0.911 & 1.074 & 1.884 & 0.141 \\
\hline
\end{tabular}


BARRAGÁN ET AL.: CAMBRIAN SCLERITES

APPENDIX 6.

Histogram values: (1) maximum diameters measured in dorsal view sclerites; (2) heights measured in lateral view sclerites.

\begin{tabular}{|c|c|c|c|}
\hline Dorsal name & $\begin{array}{l}\text { Major diameter } \\
(\text { Dmax }) \mu \mathrm{m}\end{array}$ & Lateral name & $\begin{array}{c}\text { height } \\
\mu \mathrm{m}\end{array}$ \\
\hline HD-18-01 & 142.337 & $\mathrm{H} 38-01$ & 40.523 \\
\hline HD-3-01 & 154.42 & $\mathrm{H} 29-01$ & 61.696 \\
\hline HD-2-01 & 120.553 & H13-01 & 42.183 \\
\hline HD-34-01 & 153.179 & H32-01 & 37.346 \\
\hline HD-33-01 & 145.331 & $\mathrm{H} 21-01$ & 47.617 \\
\hline HD-5-01 & 157.005 & H9-01 & 45.555 \\
\hline HD-7-01 & 162.709 & H30-01 & 65.154 \\
\hline HD-21-01 & 134.524 & $\mathrm{H} 26-01$ & 69.614 \\
\hline HD-22-01 & 124.077 & $\mathrm{H} 25-01$ & 49.856 \\
\hline $\mathrm{H} 1-01$ & 153.76 & $\mathrm{H} 6-01$ & 57.088 \\
\hline H26-01 & 133.944 & H19-01 & 52.088 \\
\hline HD-9-01 & 137.934 & $\mathrm{H} 23-01$ & 62.272 \\
\hline HD-29-01 & 138.783 & $\mathrm{H} 1-01$ & 55.29 \\
\hline HD-12-01 & 167.938 & $\mathrm{H} 20-01$ & 37.305 \\
\hline H25-01 & 137.6 & $\mathrm{H} 12-01$ & 43.498 \\
\hline HD-10-01 & 152.557 & H3-01 & 55.409 \\
\hline HD-28-01 & 159.201 & H34-01 & 54.938 \\
\hline HD-24-01 & 136.114 & H31-01 & 58.436 \\
\hline HD-32-01 & 154.497 & H8-01 & 61.14 \\
\hline HD-39-01 & 164.546 & $\mathrm{H} 10-01$ & 48.783 \\
\hline HD-36-01 & 133.911 & $\mathrm{H} 28-01$ & 38.738 \\
\hline HD-1-01 & 145.65 & $\mathrm{H} 24-01$ & 58.684 \\
\hline HD-35-01 & 182.392 & H18-01 & 34.471 \\
\hline HD-14-01 & 123.954 & HP-3-01 & 50.08 \\
\hline HD-17-01 & 190.261 & HP-4-01 & 54.951 \\
\hline HD-15-01 & 180.714 & HP-5-01 & 39.921 \\
\hline $\mathrm{H} 27-01$ & 146.566 & HP-6-01 & 42.709 \\
\hline HD-4-01 & 194.65 & HP-7-01 & 52.483 \\
\hline HD-19-01 & 179.787 & HP-9-01 & 34.506 \\
\hline $\mathrm{H} 10-01$ & 144.161 & HP-10-01 & 40.049 \\
\hline H19-01 & 199.513 & HP-11-01 & 41.419 \\
\hline HD-41-01 & 172.599 & HP-12-01 & 43.366 \\
\hline \multirow[t]{4}{*}{ HD-40-01 } & 178.53 & HP-13-01 & 57.684 \\
\hline & & HP-14-01 & 52.13 \\
\hline & & HP-15-01 & 35.028 \\
\hline & & HP-16-01 & 57.051 \\
\hline
\end{tabular}

